\title{
General vs. neuraxial anaesthesia in hip fracture patients: a systematic review and meta-analysis
}

\author{
Julia Van Waesberghe, Ana Stevanovic, Rolf Rossaint and Mark Coburn * (i)
}

\begin{abstract}
Background: Hip fracture is a trauma of the elderly. The worldwide number of patients in need of surgery after hip fracture will increase in the coming years. The 30-day mortality ranges between 4 and 14\%. Patients' outcome may be improved by anaesthesia technique (general vs. neuraxial anaesthesia). There is a dearth of evidence from randomised studies regarding to the optimal anaesthesia technique. However, several large non-randomised studies addressing this question have been published from the onset of 2010.

Methods: To compare the 30-day mortality rate, in-hospital mortality rate and length of hospital stay after neuraxial (epidural/spinal) or general anaesthesia in hip fracture patients ( $\geq 18$ years old) we prepared a systematic review and meta-analysis. A systematic search for appropriate retrospective observational and prospective randomised studies in Embase and PubMed databases was performed in the time-period from 01.01.2010 to 21.11.2016. Additionally a forward searching in google scholar, a level one reference list searching and a formal searching of trial registries was performed.
\end{abstract}

Results: Twenty retrospective observational and three prospective randomised controlled studies were included. There was no difference in the 30-day mortality [OR 0.99; $95 \% \mathrm{Cl}(0.94$ to 1.04), $p=0.60$ ] between the general and the neuraxial anaesthesia group. The in-hospital mortality [OR 0.85; $95 \% \mathrm{Cl}(0.76$ to 0.95$), p=0.004$ ] and the length of hospital stay were significantly shorter in the neuraxial anaesthesia group [MD -0.26 ; $95 \% \mathrm{Cl}(-0.36$ to -0.17$)$; $p<0.00001]$.

Conclusion: Neuraxial anaesthesia is associated with a reduced in-hospital mortality and length of hospitalisation. However, type of anaesthesia did not influence the 30-day mortality. In future there is a need for large randomised studies to examine the association between the type of anaesthesia, post-operative complications and mortality.

Keywords: Hip fracture, Neuraxial anaesthesia, General anaesthesia, 30-day mortality, In-hospital mortality, Length of hospital stay

\section{Background}

The worldwide number of hip fractures in elderly patients will rise due mainly to the demographic change from 1.66 million in the year 1990 to 6.25 million in the year 2050 [1]. Furthermore, elderly hip fracture patients present an array of comorbidities which are associated with an increased risk of morbidity and mortality [2]. The one-month mortality ranges from 4 to $14 \%[3-6]$.

\footnotetext{
* Correspondence: mcoburn@ukaachen.de

Department of Anaesthesiology, University Hospital RWTH Aachen,

Pauwelsstraße 30, 52074 Aachen, Germany
}

Thus far, the ideal anaesthetic technique (general vs. neuraxial anaesthesia) has not been identified. The most recent randomised studies were condensed in a metaanalysis which was performed in the year 2016. The systematic review of Guy and colleagues included 31 randomised studies published between 1977 and 2013 [7]. However, only 28 studies comprising 2.976 patients could be included for the meta-analysis. Therefore, there is a high bias risk. Obviously the studies have been incapable of addressing, for example, a distinction in the 30-day mortality. Furthermore, there has been a change in clinical practice since 1977 [7]. However, since 2010

(c) The Author(s). 2017 Open Access This article is distributed under the terms of the Creative Commons Attribution 4.0 International License (http://creativecommons.org/licenses/by/4.0/), which permits unrestricted use, distribution, and reproduction in any medium, provided you give appropriate credit to the original author(s) and the source, provide a link to the Creative Commons license, and indicate if changes were made. The Creative Commons Public Domain Dedication waiver (http://creativecommons.org/publicdomain/zero/1.0/) applies to the data made available in this article, unless otherwise stated. 
several large scale non-randomised studies have been published [8-27]. The objective of the present systematic review and meta-analysis is to provide a six-year overview of the literature assessing the influence of the anaesthetic technique for hip fracture surgery in prospective randomised and retrospective observational studies.

\section{Methods}

\section{Protocol and registration}

The study protocol has not been previously published. The manuscript has been prepared according to criteria of the PRISMA checklist and guidelines for systematic reviews and meta-analyses [28]. This systematic review and meta-analysis was registered in the international prospective register of systematic reviews (Prospero: CRD42016033254).

\section{Eligibility criteria}

Before carrying out the systematic review and metaanalysis the exclusion and inclusion criteria were predefined by all authors. We included only human studies, which were published between 01.01.2010 and 21.11.2016 and assessed advantages of the applied anaesthetic technique general vs. neuraxial anaesthesia (epidural or spinal) in adult ( $\geq 18$ years old) hip fracture patients. Prospective randomised and observational studies were included, which addressed the 30-day mortality, in-hospital mortality or length of hospital stay. As secondary outcome we examined the postoperative incidence of myocardial infarction, pneumonia, pulmonary embolism and respiratory failure after hip fracture surgery. We excluded case series and systematic reviews. Studies of all languages were included in the search.

\section{Information sources and search}

In March 2017 a systematic search was performed via the database PubMed and Embase. The search term "anesthesia and hip fracture" or "anaesthesia and hip fracture" was used in both databases. Additionally, one study was included which was not identified via the systematic literature search [10]. The full search strategy for PubMed was: (("anaesthesia"[All Fields] OR "anesthesia" [MeSH Terms] OR "anesthesia"[All Fields]) AND ("hip fractures" [MeSH Terms] OR ("hip" [All Fields] AND "fractures" [All Fields]) OR "hip fractures" [All Fields] OR ("hip" [All Fields] AND "fracture" [All Fields]) OR "hip fracture" [All Fields])) AND ("2010/ 01/01" [PDat]: "2016/11/21" [PDat]) and for Embase: $((\mathrm{AU}=$ Anesthesia? OR (Anesthesia\#)) AND $(\mathrm{AU}=\mathrm{HIP}$ ? OR $((\mathrm{HIP} \#))$ AND $(\mathrm{AU}=$ FRACTURE? OR (FRACT\#\#\#))) AND PY = 2010 to 2016. Additionally, a forward searching in google scholar, a level one reference list searching and a formal searching of trial registries (https://clinicaltrials.gov/; www.who.int/ictrp/en/ (international clinical trials registry platform) Search Portal of the World Health Organization) was performed. The results of the study of White and colleagues for the hospital length of stay was provided by one of the Co- authors [26].

\section{Study selection and data collection}

JVW conducted the literature search and screened all hits based on the full text. Additionally, MC and AS verified all hits for eligibility independently. Only human studies, prospective randomised and retrospective observational studies were included. Case series and systematic reviews were excluded.

\section{Data items}

A standardised table based on the PICO approach was made to reveal the salient results [28]. It contains the study type, applied anaesthetic technique, the sample size, primary and secondary outcome variables, summarized results and conclusion. We carried out a metaanalysis for the 30-day mortality, the in-hospital mortality and the length of hospital stay. In addition, we assessed as secondary outcome the postoperative incidence of myocardial infarction, pneumonia, pulmonary embolism and respiratory failure and performed a metaanalysis.

\section{Assessment of risk of bias}

In order to assess bias risk, the Cochrane Collaboration's tool for randomised studies was applied. The five domains of bias were classified as high, moderate or low risk. Regarding the non-randomised studies the Cochrane ACROBAT-NRSI tool was used. The seven domains of bias were also classified as high, moderate or low risk, accordingly.

\section{Statistics}

The meta-analyses were performed using the RevMan 5.3 software. Due to the clinical and methodological heterogeneity of the included studies a random-effects model was applied for the meta-analysis. $P$-values less than 0.05 were regarded as statistically significant in the seven meta-analyses. The standard deviation (SD) was calculated, if not mentioned, based on the range (Maximum-Minimum) $/ 4$ or based on the $95 \%$ confidence interval $[\mathrm{SD}=\sqrt{ } \mathrm{N} \times$ (upper limit-lower limit)/ 3.92)] or on the Interquartile Range (IQR) [SD = IQR/ 1.35], whichever was available.

\section{Results}

Study selection

The search in PubMed identified 465 and in Embase 825 studies. The forward searching in google scholar revealed 
538 studies, the list one reference searching 662 studies and the formal searching of trials registries 91 studies (clinicaltrials.gov $n=71$; ICTRP $n=20$ ) After removing the duplicates, we screened 1693 studies. Case reports, systematic reviews and meta-analyses were excluded. The study from Helwani and colleagues was included without being identified via our search term ("anesthesia and hip fracture" and "anaesthesia and hip fracture") [10]. Finally 25 full text articles were assessed for eligibility. Two fulltext articles were excluded as the outcome parameters did not fit the outcome variables of this study. One study did not define the meaning of the term "local anesthesia", another study described the postoperative length of stay without usable values for our systematic review. The aim of Basques and colleagues was to identify factors, associated with an increased length of stay after hip fracture surgery, like the type of surgery [29, 30]. In total 23 studies were included for this systematic review and metaanalysis, see Fig. 1. [8-27, 31-33].

\section{Study characteristics/participants}

Twenty retrospective observational studies and three randomised controlled studies were included [8-27,
31-33]. Overall 413.999 patients were analysed in this systematic review and meta-analysis. 249.408 patients received general anaesthesia and 150.964 patients received neuraxial anaesthesia (spinal anaesthesia and in some cases epidural anaesthesia). Our aim was to include only adult patients with a hip fracture over than 18 years. The study of Rashid and colleagues included patients with an age of 14-98 years. The mean age in the study was 65 . Therefore, we decided to include this study in our systematic review [17]. Sample sizes in the included studies varied widely. The largest study included 104.088 patients and the smallest one 45 patients, see Table 1 [25, 32].

\section{Risk of bias within and across studies}

Analyses of the risk of bias for retrospective observational studies and randomised controlled studies are described in Tables 2 and 3, respectively.

\section{Results of individual studies Mortality}

Fourteen studies examined the effect of general vs. neuraxial anaesthesia on the 30-day mortality after hip

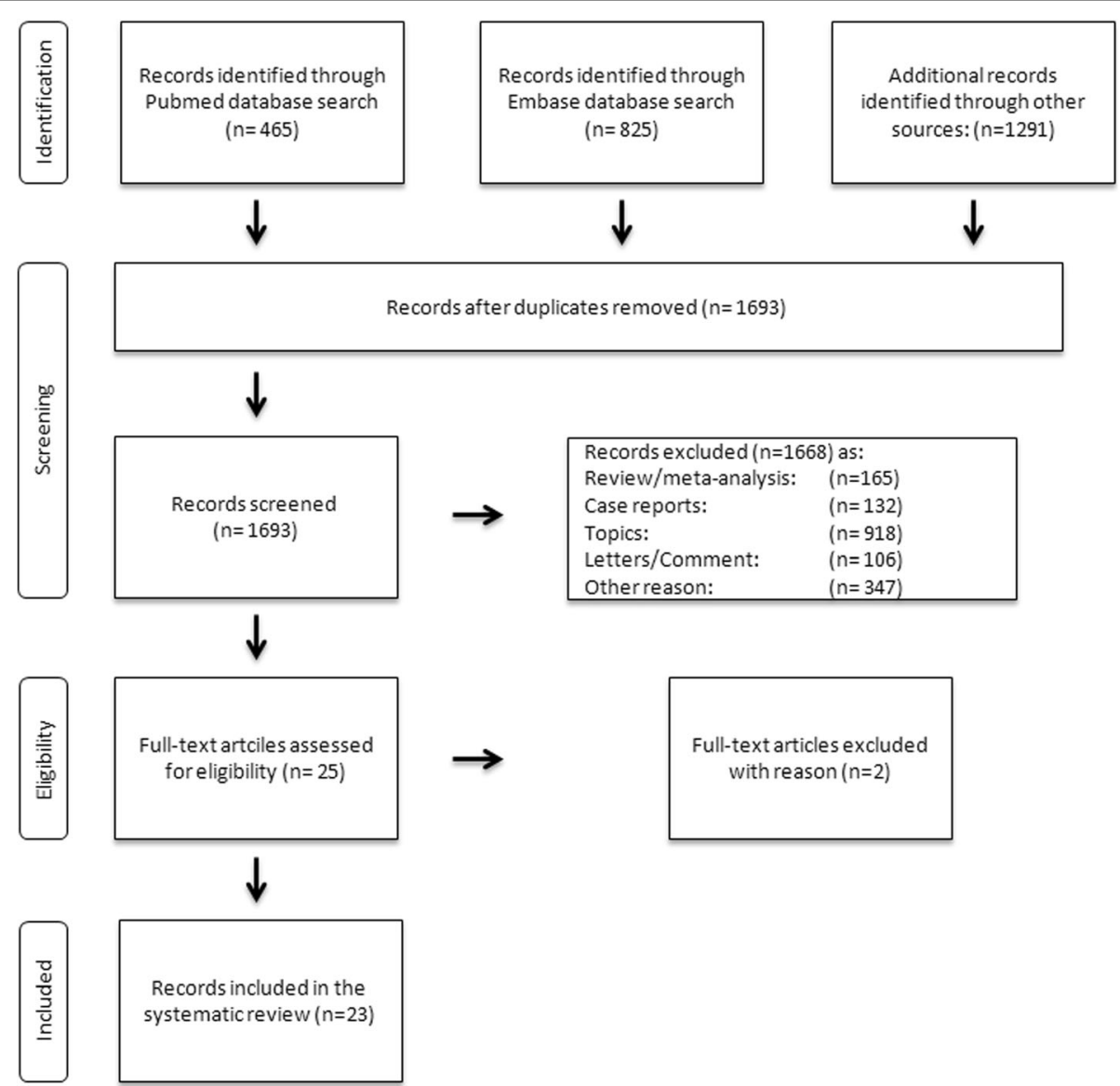

Fig. 1 Prisma-flow diagram for the literature search and exclusion criteria 


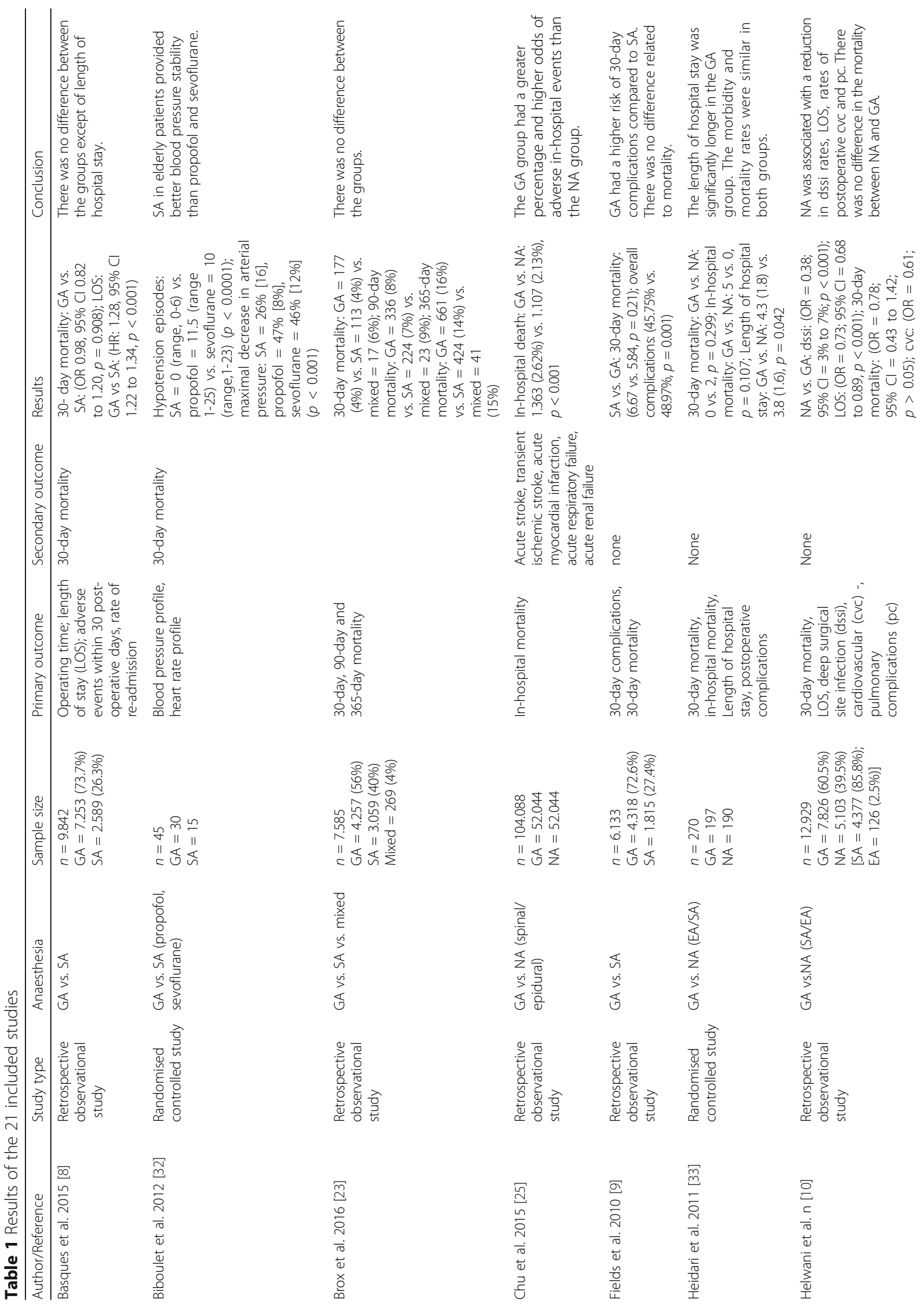




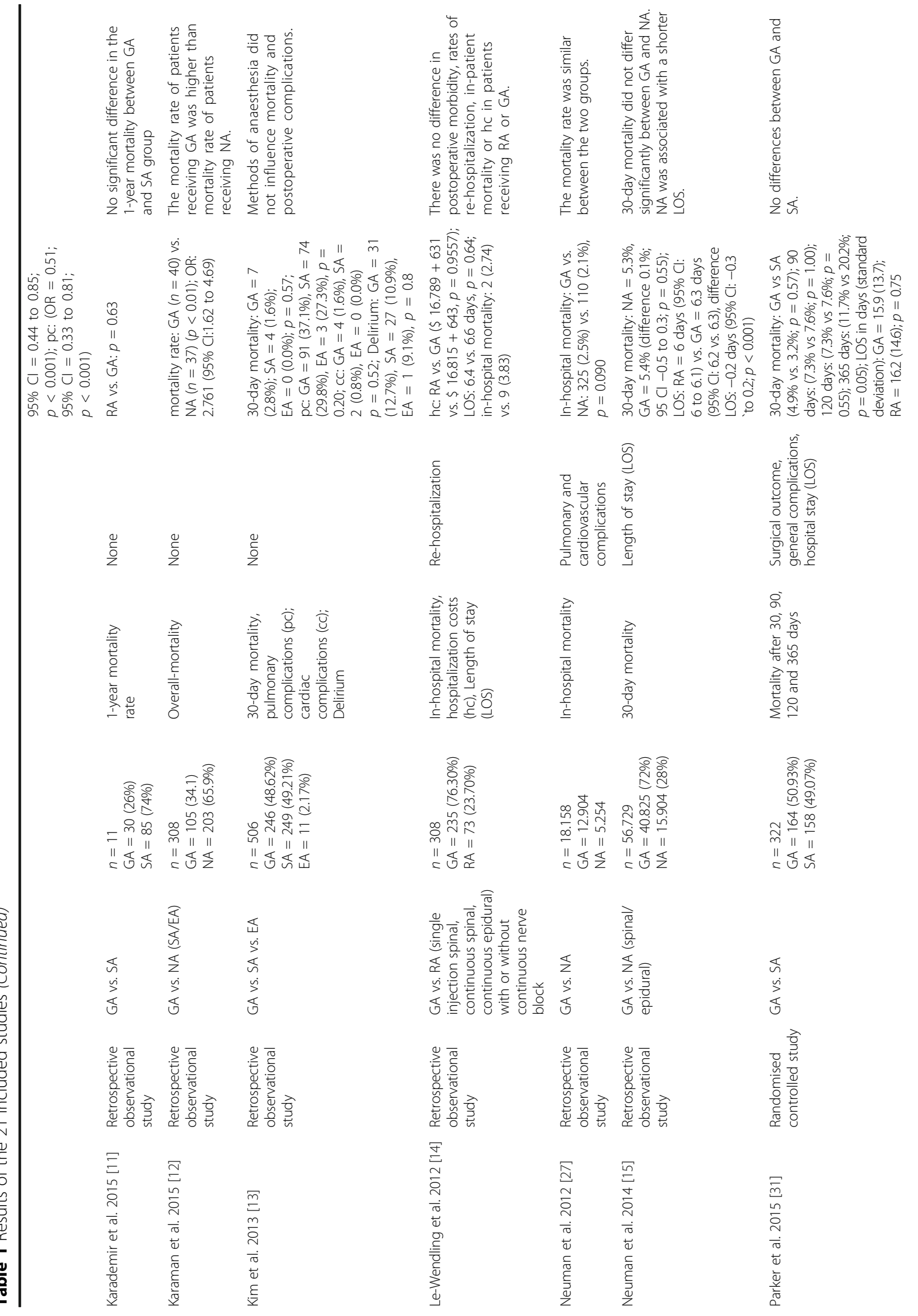




\begin{tabular}{|c|c|c|c|c|c|}
\hline 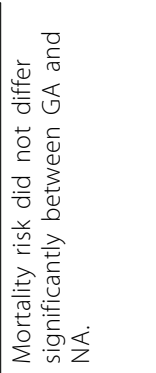 & 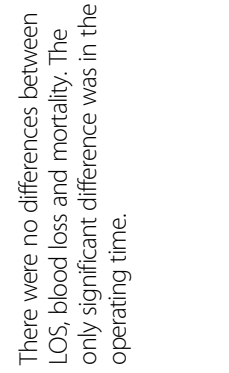 & 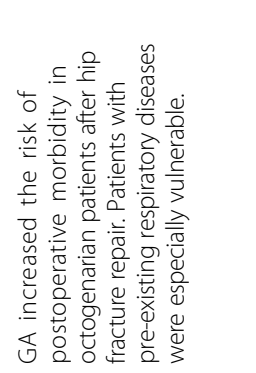 & 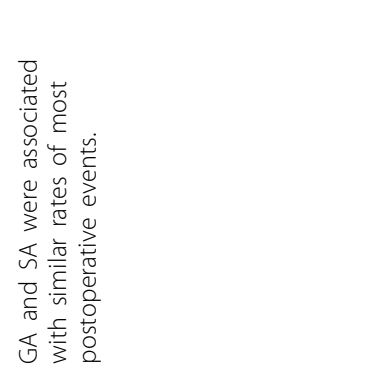 & 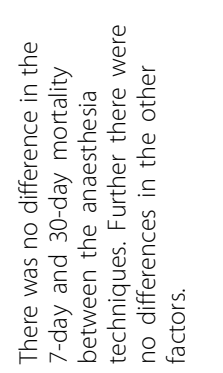 & 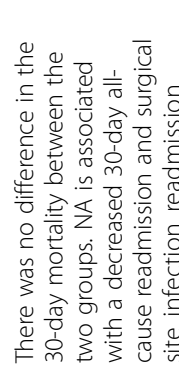 \\
\hline 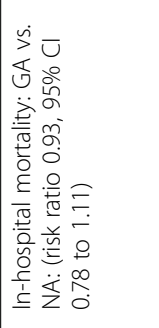 & 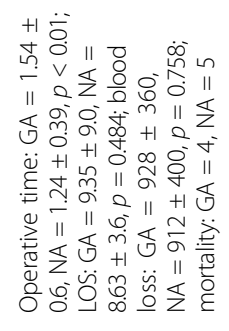 & 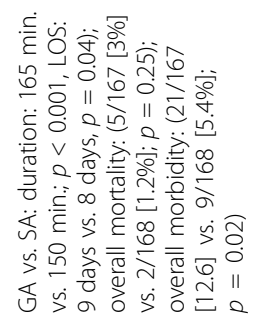 & 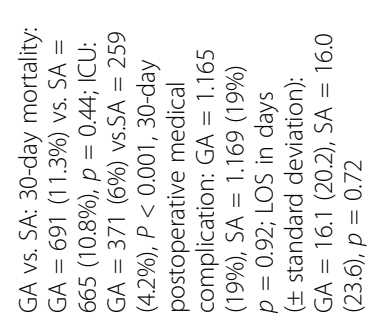 & 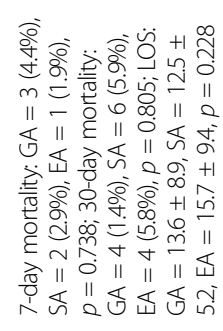 & 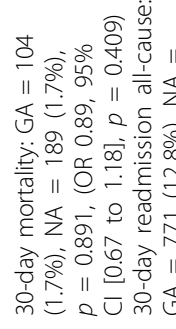 \\
\hline 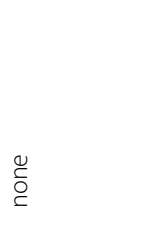 & $\stackrel{\check{\partial}}{\check{0}}$ & $\stackrel{\mathscr{\nu}}{0}$ & 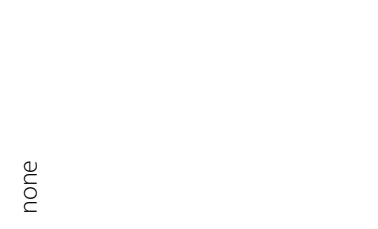 & 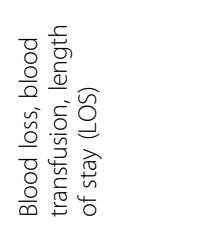 & \\
\hline & 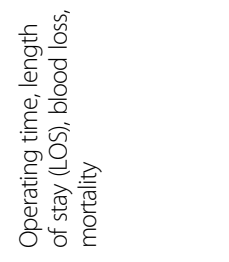 & 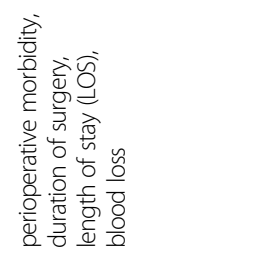 & 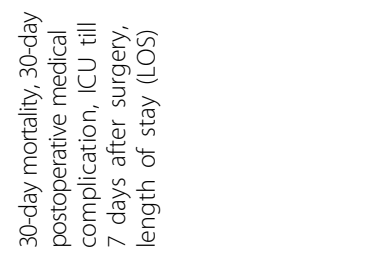 & 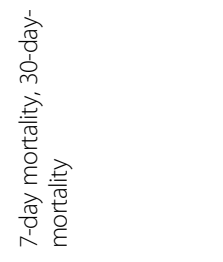 & 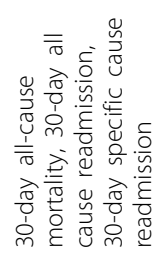 \\
\hline 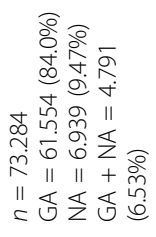 & 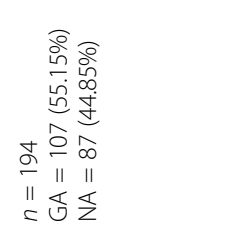 & 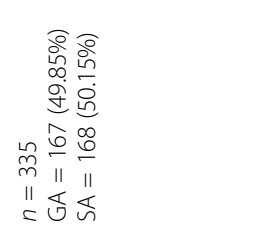 & 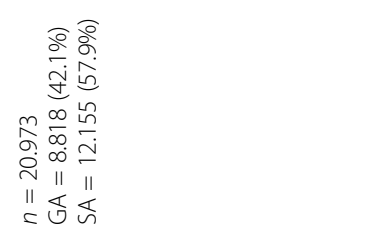 & 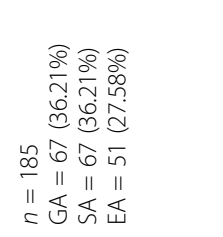 & 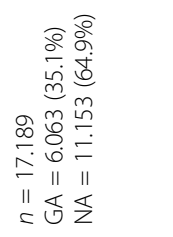 \\
\hline 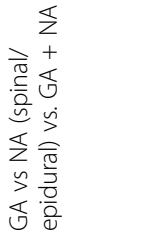 & 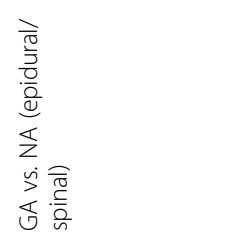 & \begin{tabular}{l}
$\mathbb{a}$ \\
s \\
\multirow{3}{*}{} \\
0
\end{tabular} & 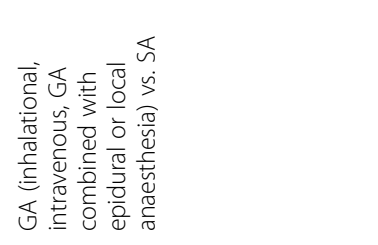 & 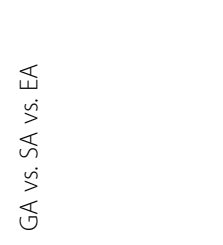 & 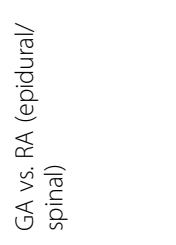 \\
\hline 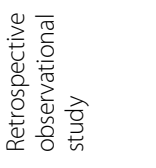 & 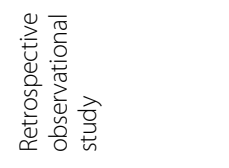 & 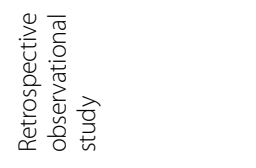 & 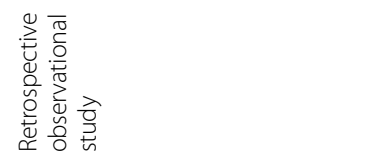 & 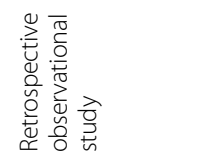 & 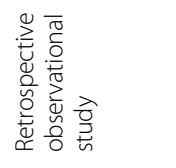 \\
\hline 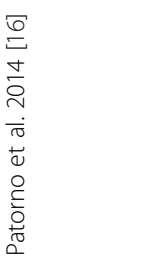 & 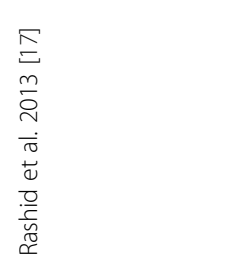 & 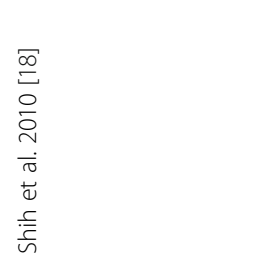 & 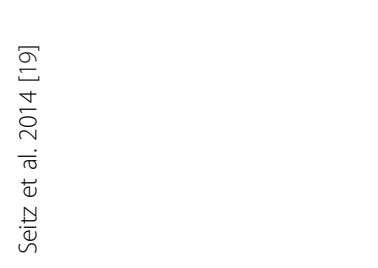 & 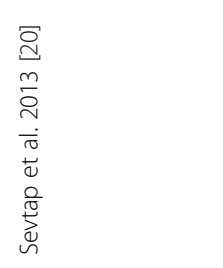 & 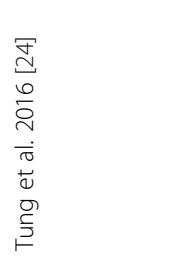 \\
\hline
\end{tabular}




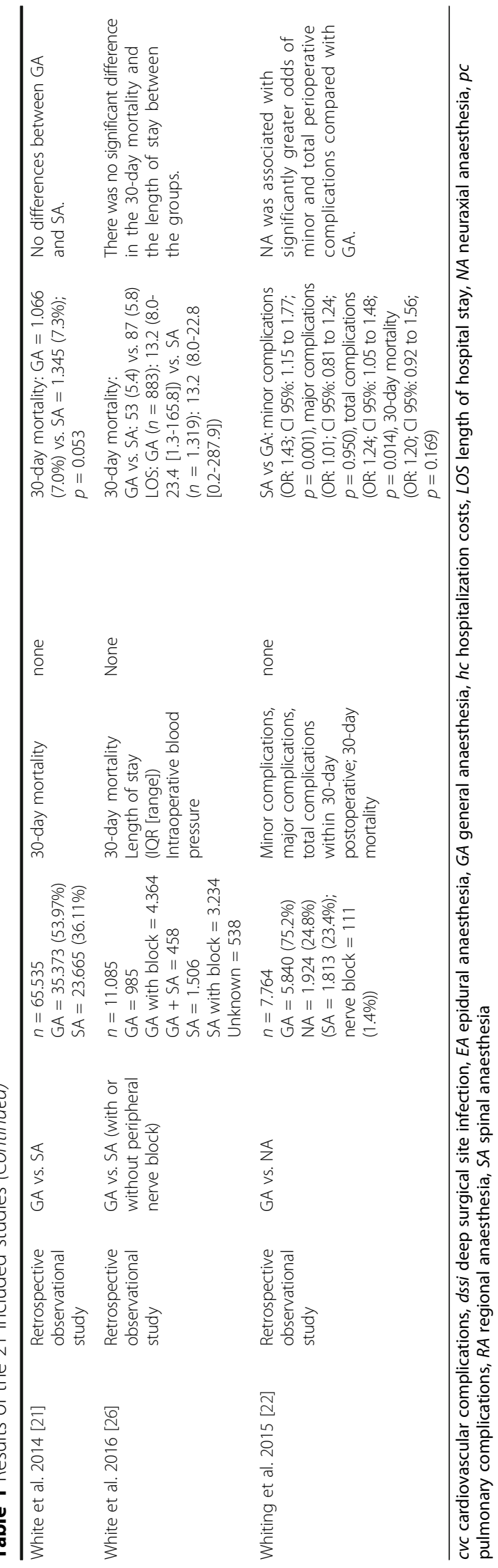




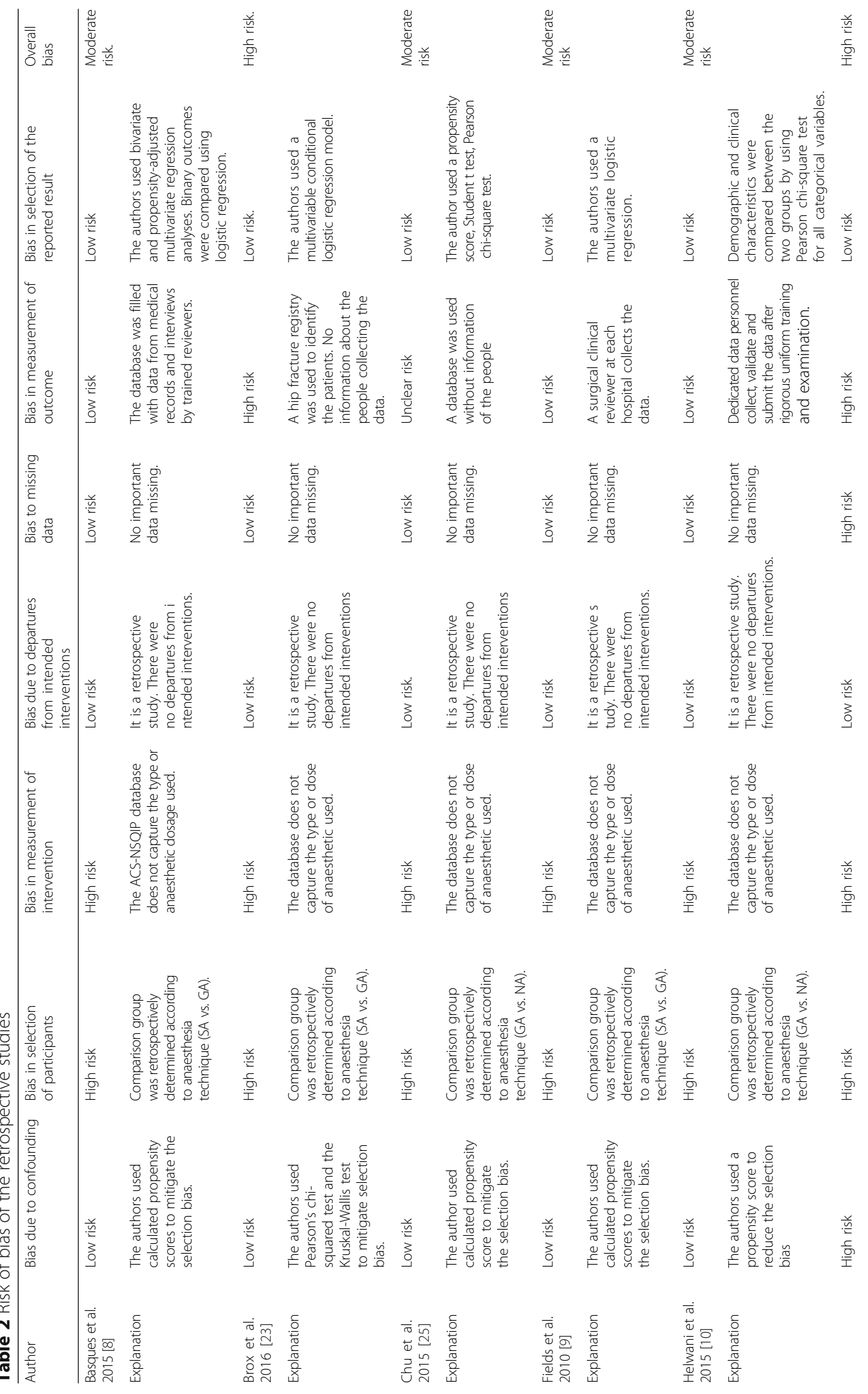




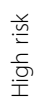

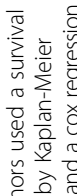

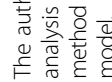

兽䍃

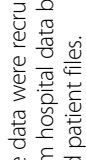

送

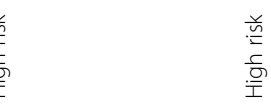

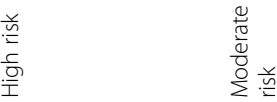
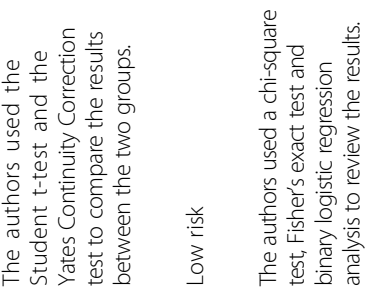

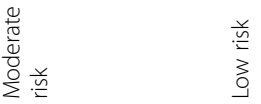

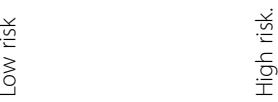
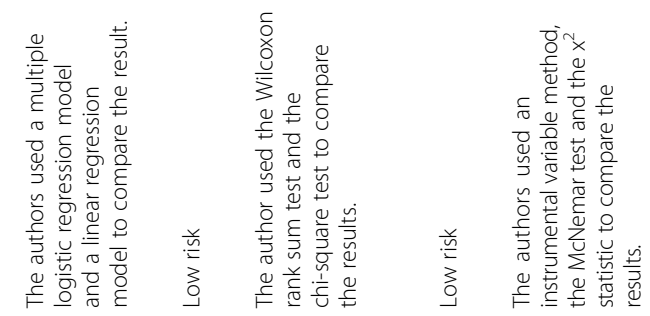

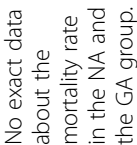
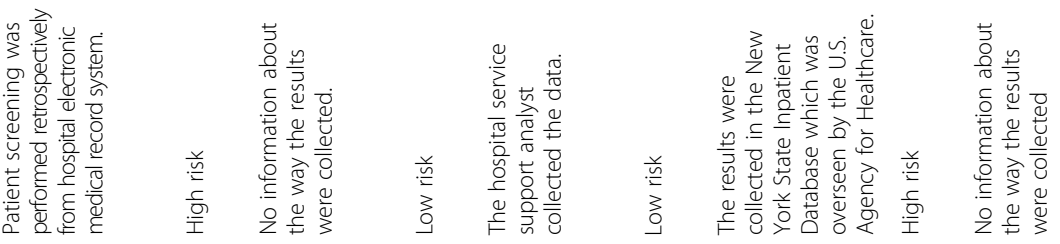

(2)
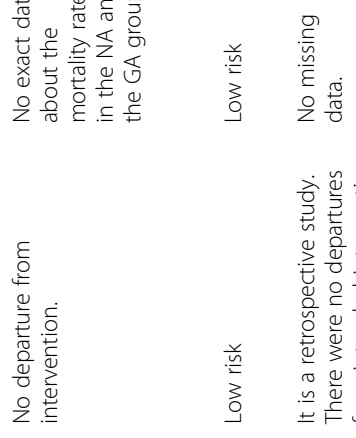

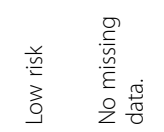

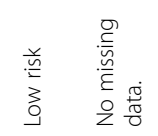

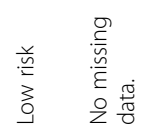

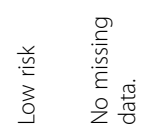<smiles>C1CC2CCC1C2</smiles>

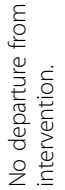

这

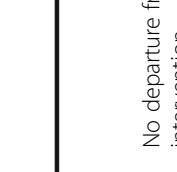

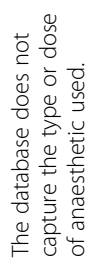

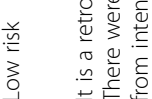<smiles>C[C@H]1C[C@H]2C[C@@H]1C2</smiles><smiles>C[C@H]1C[C@H]2C[C@@H]1C2</smiles><smiles>C[C@H]1[C@@H]2C[C@@H]1[C@H]2C</smiles><smiles>C[C@H]1C[C@H]2C[C@@H]1C2</smiles>

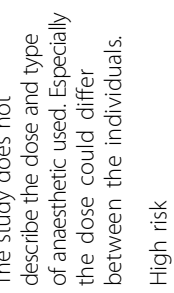

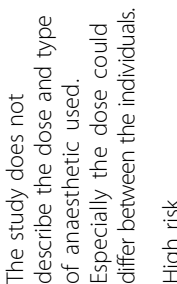

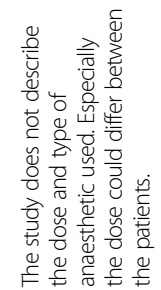

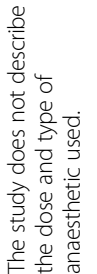

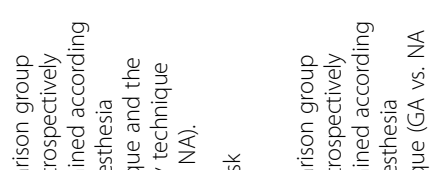

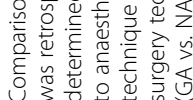

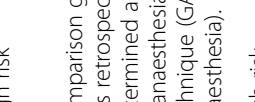

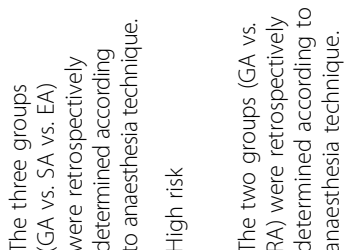

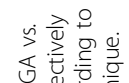
专穿亭

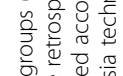

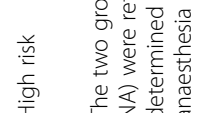

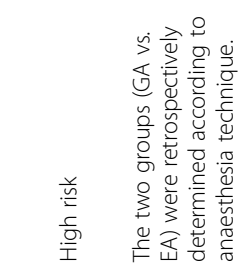

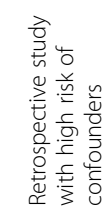

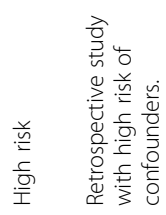

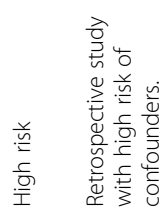

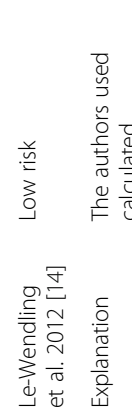

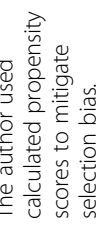

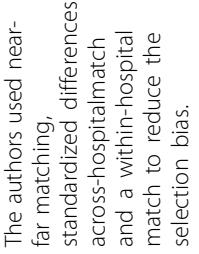

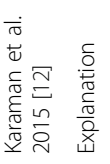

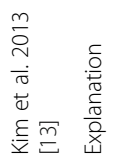

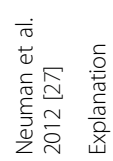

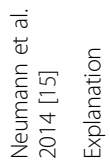




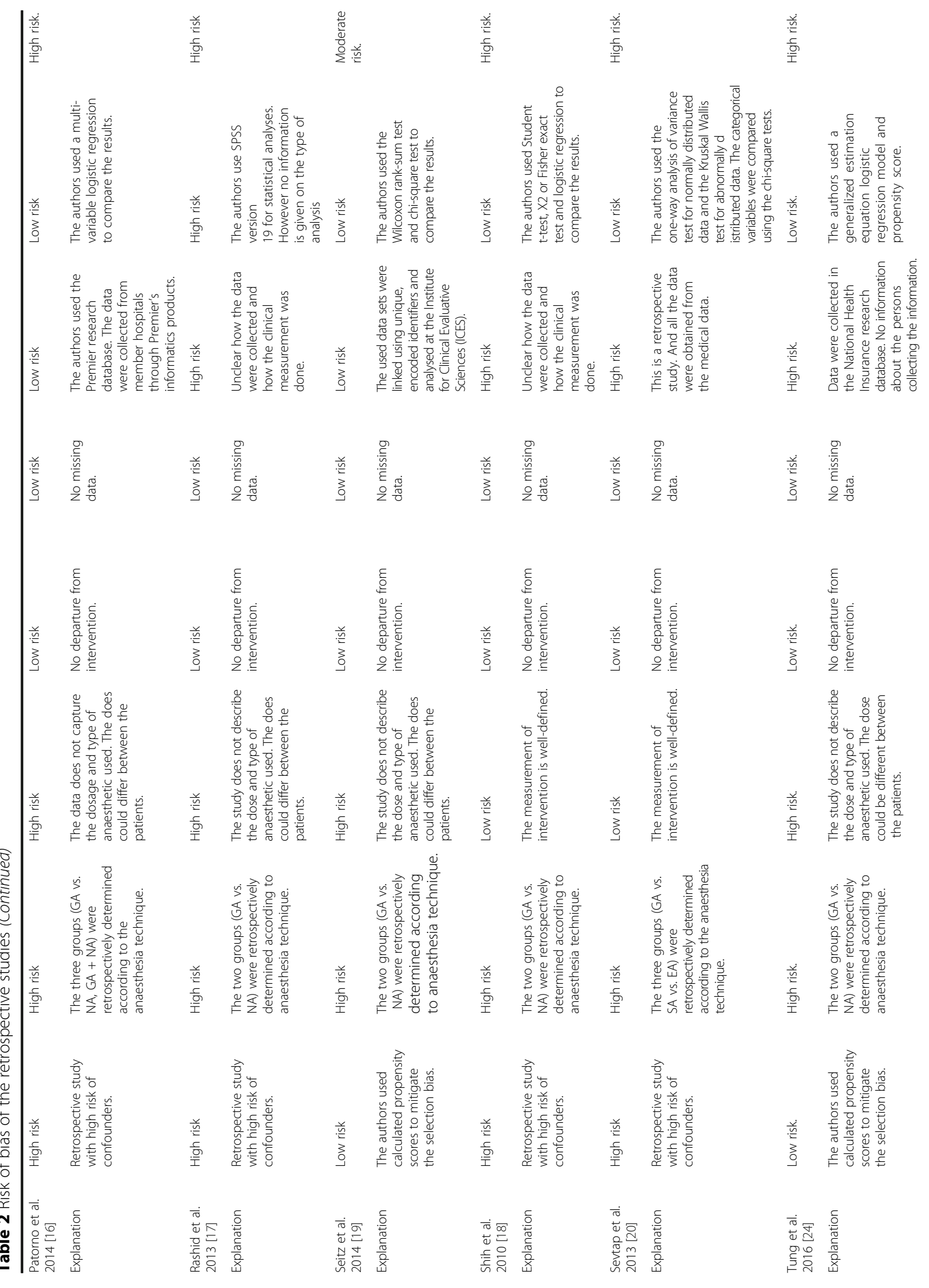




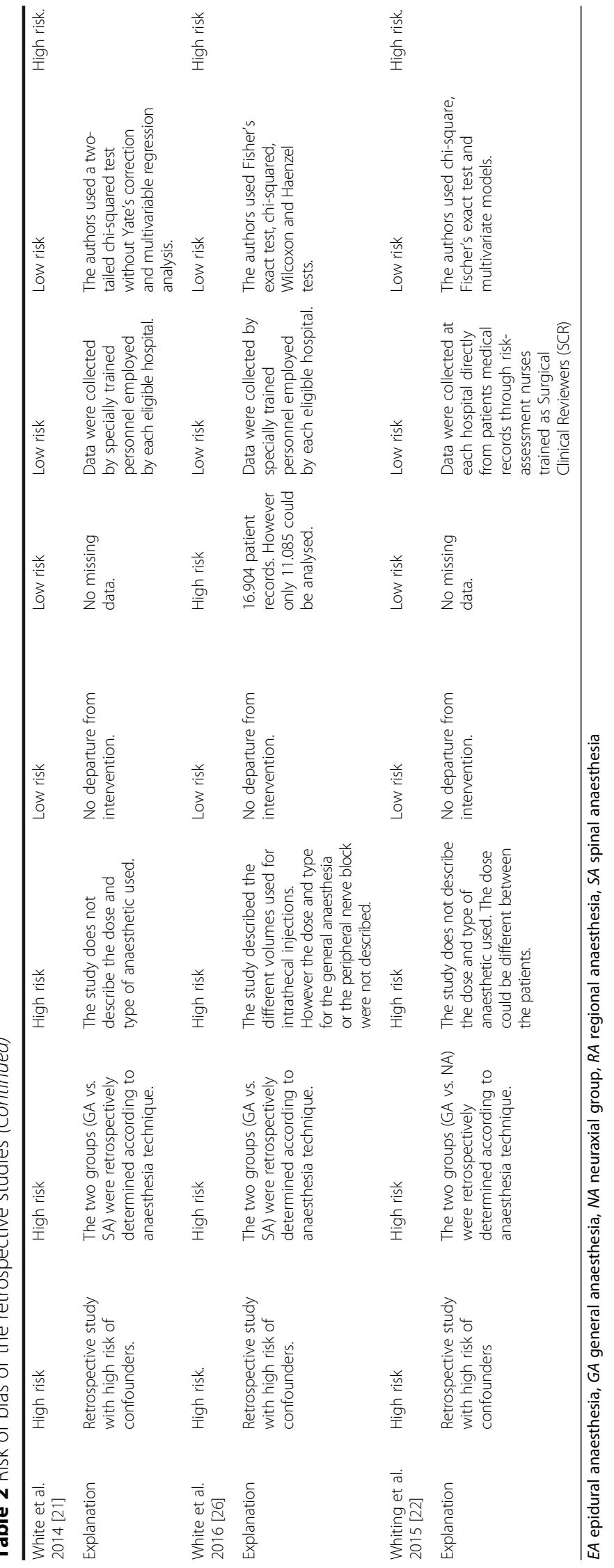




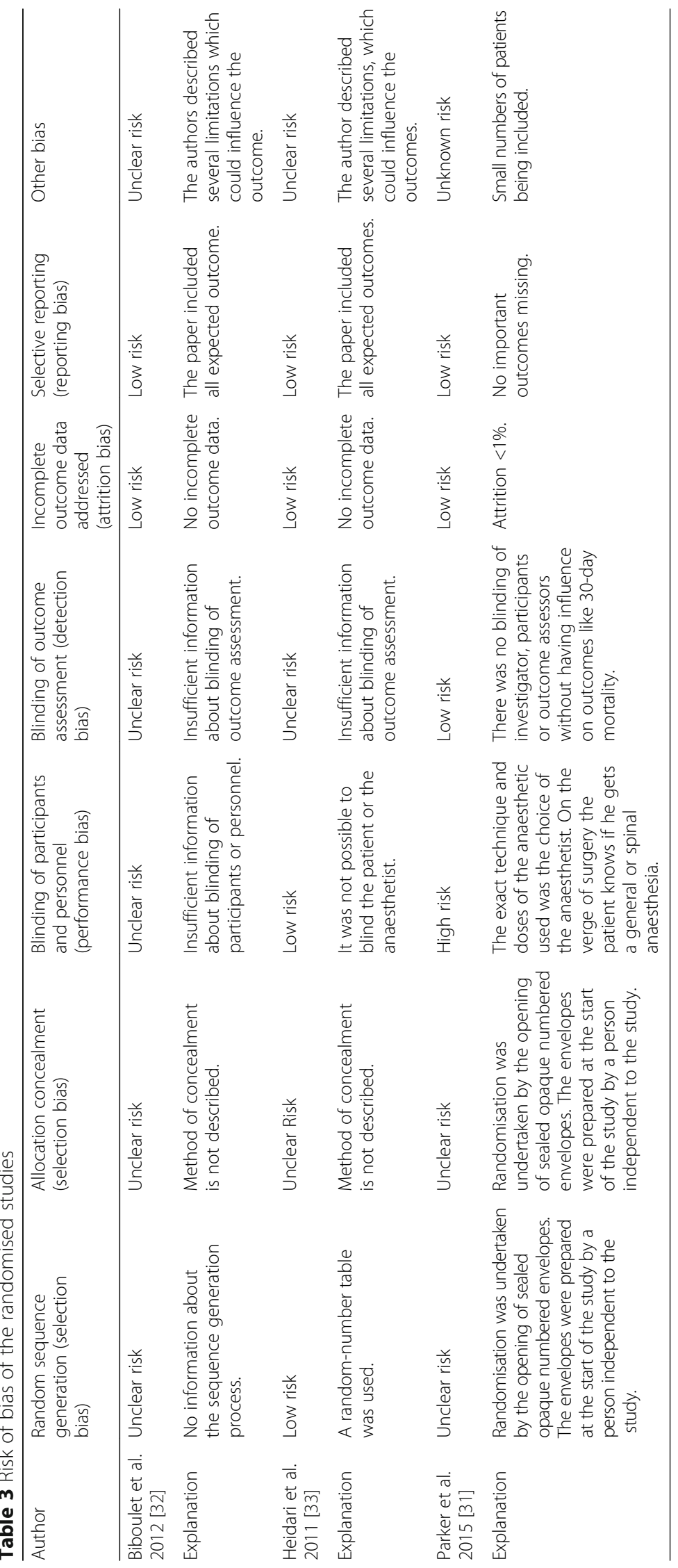


fracture surgery in adults. Eleven were retrospective observational and three were prospective randomised studies [8-10, 13, 15, 19-21, 23, 24, 26, 31-33].All assessed studies could not identify a difference between the 30-day mortality, see Table 4. The metaanalysis including the fourteen studies revealed no significant difference for the 30-day mortality [Odds Ratio (OR) 0.99; 95\% Confidence Interval (CI) (0.94 to 1.04), $p=0.60][8-10,13,15,19-21,23,24,26,31-33]$. We performed a separate subgroup analysis of the eleven retrospective observational and the three randomised controlled studies. Both subgroup-analyses revealed no significant difference in the 30-day mortality between the two groups [OR $0.99,95 \%$ CI $(0.93$ to 1.04), $p=0.58$ ] vs. [OR $0.92,95 \%$ CI $(0.34$ to 2.51$)$, $p=0.88]$, see Fig. 2 .

Two studies assessed the overall mortality $[12,18]$. Karaman and colleagues $(n=308$, general anaesthesia $=105$, neuraxial anaesthesia $=203$ ) revealed that there is a higher mortality rate after receiving general anaesthesia than neuraxial anaesthesia [12]. Shih $(n=335$, general anaesthesia $=167$, neuraxial anaesthesia $=168$ ) and colleagues indicated that the overall-mortality is not significantly different between the general anaesthesia and the neuraxial anaesthesia group. Of note, general anaesthesia increased the risk of overall-morbidity in patients after hip fracture surgery in this study. Patients with preexisting respiratory diseases were especially vulnerable [18].

The retrospective study of Karademir and colleagues and the randomised controlled study of Parker and Griffiths examined the 1-year mortality. In both studies there is no significant difference in the 1-year mortality between the neuraxial and the general anaesthesia group $[21,31]$.

The in-hospital mortality was examined by five studies, see Table 5. Four studies came to the result that the in-hospital mortality rate did not differ significantly between general and neuraxial anaesthesia $[14,16,27,33]$. The study of $\mathrm{Chu}$ and colleagues $(n=104.088$, general anaesthesia $=52.044$, neuraxial anaesthesia $=52.044)$ revealed a significant higher incidence of the in-hospital mortality in the general anaesthesia group. Our meta-analysis, including the aforementioned five studies, showed a significant lower incidence of the in-hospital mortality in the neuraxial anaesthesia group. [OR $0.85 ; 95 \%$ CI $(0.76$ to 0.95$), p=0.004$ ] with a negligible heterogeneity $\left(\mathrm{I}^{2}=28 \%\right)$, see Fig. 3. [14, 16, 25, 27, 33].

\section{Length of hospital stay}

Twelve studies examined the length of hospital stay (LOS), see Table 6. [8, 10, 14, 15, 17-20, 25, 26, 31, 33].
Six studies revealed no difference in length of hospital stay related to the anaesthetic technique $[14,17,19,20$, $26,31]$. One study reported that general anaesthesia was associated with a shorter length of stay [Hazard Ratio (HR): $1.28,95 \%$ CI (1.22 to 1.34$) ; p<0.001$ ] [8]. In contrast five other studies showed that neuraxial anaesthesia was associated with a shorter length of hospital stay [10, $15,18,25,33]$. Nine of the twelve studies were included in the meta-analysis $[10,15,17,19,20,25,26,31,33]$. In the meta-analysis we found a significantly shorter length of stay in the neuraxial anaesthesia group [Mean Difference (MD): $-0.26 ; 95 \%$ CI $(-0.36$ to -0.17$)$; $p<0,00001]$. The heterogeneity was moderate with $\mathrm{I}^{2}=53 \%$, see Fig. 4 . We made a separate subgroup analysis for the retrospective observational and the randomised controlled studies. The subgroup analysis for the retrospective observational studies indicates a significant shorter length of stay in the hospital in the neuraxial anaesthesia group. [MD $-0.26,95 \% \mathrm{CI}(-0.35$ to -0.16$)$, $p<0.00001]$. The subgroup analysis for the randomised controlled studies revealed no difference between the two groups. [MD: $-0.65,95 \%$ CI $(-1.32$ to -0.01$)$, $p=0.06]$, see Fig. 4 .

\section{Secondary outcomes \\ Cardiac complications/myocardial infarction}

Three studies examined the total rate of any cardiac complications after hip fracture surgery [10, 13, 27]. Helwani and colleagues reported that neuraxial anaesthesia is associated with a decreased risk of postoperative cardiac [OR: $0.61 ; 95 \%$ CI $(0.44$ to 0.85$)$; $p<0.001$ ] complications [10]. Kim and colleagues and Neuman and colleagues determined that the methods of anaesthesia did not influence the rate of cardiac complications [13, 27].

Ten studies examined the incidence of myocardial infarction after hip fracture surgery in the general anaesthesia and the neuraxial anaesthesia groups, see Table 7 $[8,9,19,22,24,25,27,31-33]$. All studies are in unison that there is no difference between the two groups. Nine studies could be included in a meta-analysis $[8,9,19,24$, 25, 31-33]. The meta-analysis came to the result that the incidence of postoperative myocardial infarction is significant higher in the general anaesthesia group [OR $0.90,95 \%$ CI (0.82 to 0.99), $p=0.03$ ], see Fig. 5. The separate subgroup analysis for the retrospective observational studies revealed a significant higher incidence of myocardial infarction in the general anaesthesia group [OR $0.90,95 \%$ CI (0.82 to 0.99$), p=0.03$ ]. The subgroup of the three randomised controlled studies represents no difference between the two groups [OR 0.91, 95\% CI (0.17 to 4.90$), p=0.91]$. The heterogeneity was in all cases $\mathrm{I}^{2}=0$. 


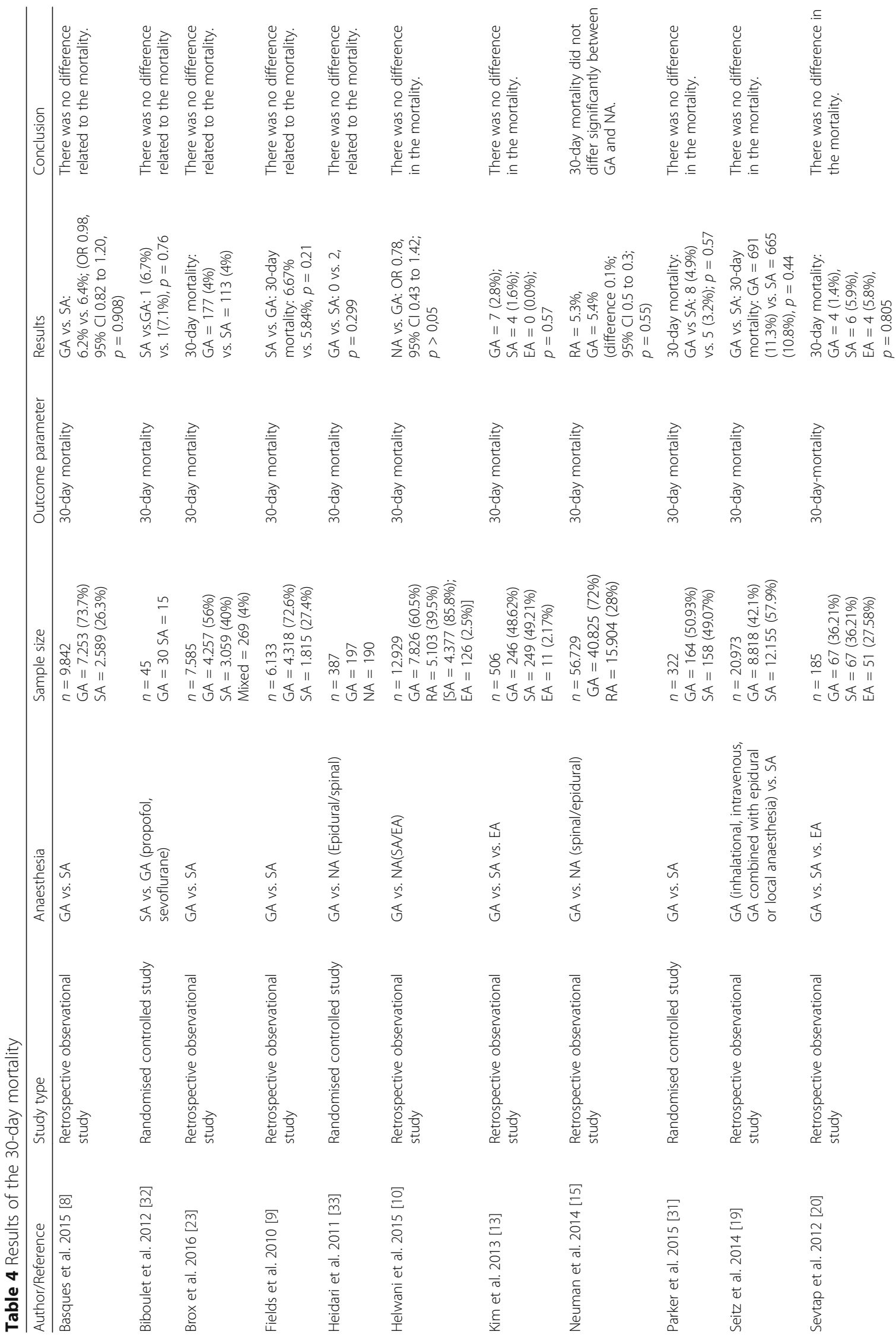


Waesberghe et al. BMC Anesthesiology (2017) 17:87

Page 15 of 25

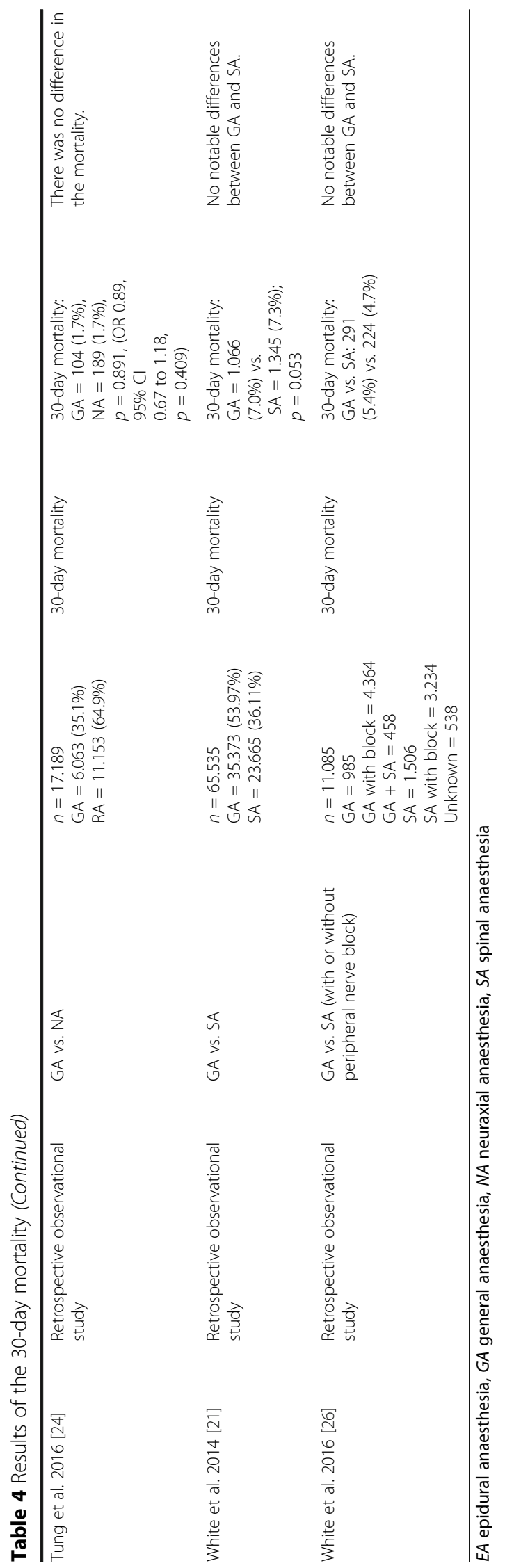




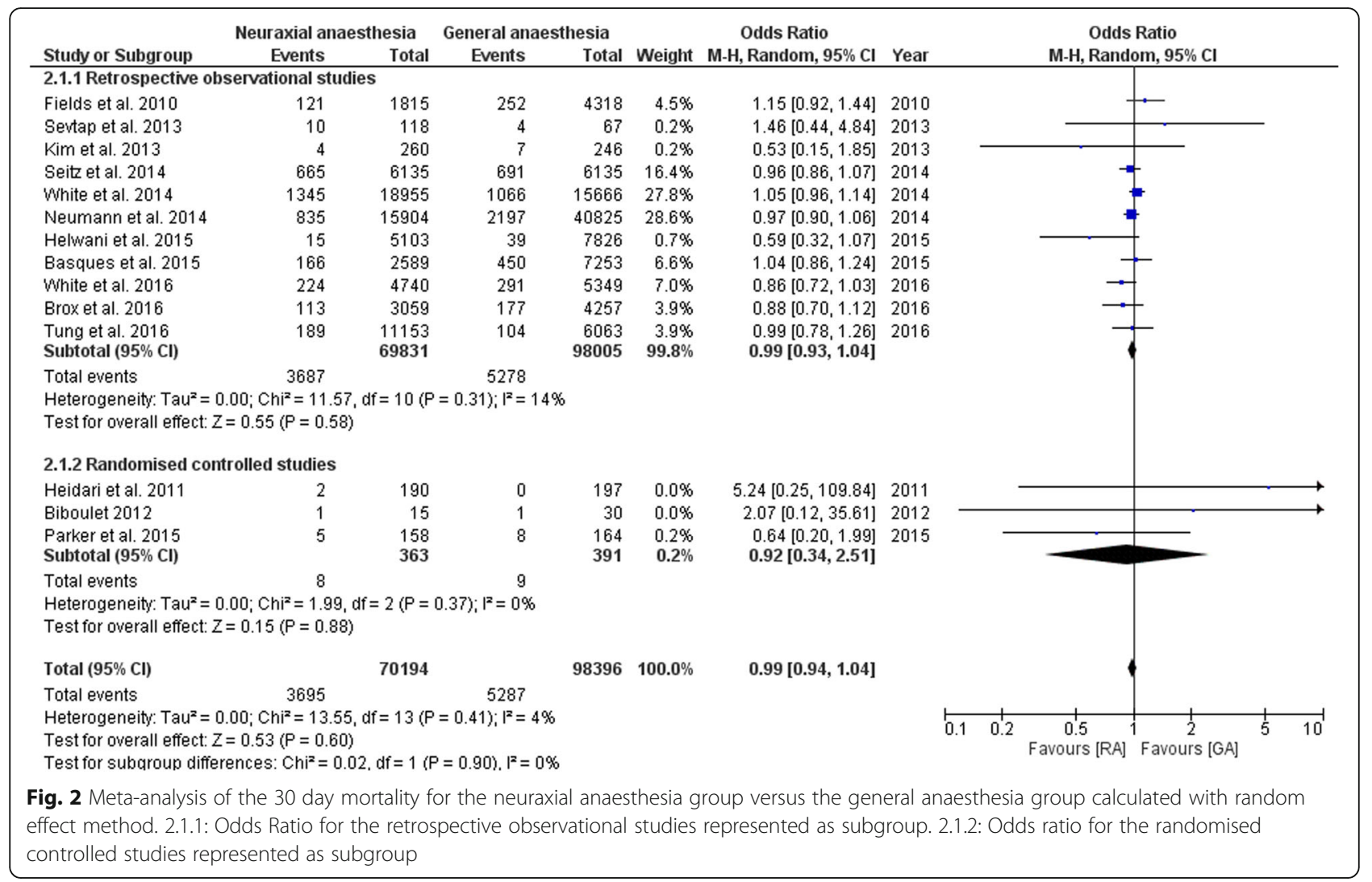

Table 5 Results of the in-hospital mortality

\begin{tabular}{|c|c|c|c|c|c|c|}
\hline Author/Reference & Study type & Anaesthesia & Sample size & $\begin{array}{l}\text { Outcome } \\
\text { parameter }\end{array}$ & Results & Conclusion \\
\hline $\begin{array}{l}\text { Chu et al. } \\
2015[25]\end{array}$ & $\begin{array}{l}\text { Retrospective } \\
\text { observational study }\end{array}$ & $\begin{array}{l}\text { GA vs. NA (spinal/ } \\
\text { epidural) }\end{array}$ & $\begin{array}{l}n=104.088 \\
\mathrm{GA}=52.044 \\
\mathrm{NA}=52.044\end{array}$ & $\begin{array}{l}\text { In-hospital } \\
\text { mortality }\end{array}$ & $\begin{array}{l}\text { GA vs. NA: } 1.363 \\
(2.62 \%) \text { vs. } 1.107 \\
(2.13 \%), p<0.001\end{array}$ & $\begin{array}{l}\text { The incidence of } \\
\text { on-hospital mortality } \\
\text { was significantly } \\
\text { lower in the NA group. }\end{array}$ \\
\hline $\begin{array}{l}\text { Heidari et al. } \\
2011 \text { [33] }\end{array}$ & $\begin{array}{l}\text { Randomised } \\
\text { controlled study }\end{array}$ & $\begin{array}{l}\text { GA vs. NA (epidural/ } \\
\text { spinal) }\end{array}$ & $\begin{array}{l}n=270 \\
G A=197 \\
N A=190\end{array}$ & $\begin{array}{l}\text { In-hospital } \\
\text { mortality }\end{array}$ & $\begin{array}{l}\text { GA vs. NA: } 0 \text { vs. } 5 \\
p=0.107\end{array}$ & $\begin{array}{l}\text { The incidence of } \\
\text { in-hospital mortality } \\
\text { was similar in both } \\
\text { groups. }\end{array}$ \\
\hline $\begin{array}{l}\text { Le-Wendling et al. } \\
2012 \text { [14] }\end{array}$ & $\begin{array}{l}\text { Retrospective } \\
\text { observational study }\end{array}$ & $\begin{array}{l}\text { GA vs. RA (single injection } \\
\text { spinal, continuous spinal, } \\
\text { continuous epidural) with } \\
\text { or without continuous } \\
\text { nerve block }\end{array}$ & $\begin{array}{l}n=308 \\
\mathrm{GA}=235(76.30 \%) \\
\mathrm{RA}=73(23.70 \%)\end{array}$ & $\begin{array}{l}\text { In-hospital } \\
\text { mortality }\end{array}$ & $\begin{array}{l}\text { RA vs. GA: } 2 \text { (2.74) } \\
\text { vs. } 9 \text { (3.83) }\end{array}$ & $\begin{array}{l}\text { There was no } \\
\text { difference between } \\
\text { the in-hospital } \\
\text { mortality. }\end{array}$ \\
\hline $\begin{array}{l}\text { Neuman et al. } \\
2012 \text { [27] }\end{array}$ & $\begin{array}{l}\text { Retrospective } \\
\text { observational study }\end{array}$ & GA vs. NA & $\begin{array}{l}n=18.158 \\
G A=12.904 \\
N A=5.254\end{array}$ & $\begin{array}{l}\text { In-hospital } \\
\text { mortality }\end{array}$ & $\begin{array}{l}\text { GA vs NA } 325(2.5 \%) \\
\text { vs. } 110(2.1 \%), p=0.090\end{array}$ & $\begin{array}{l}\text { There was no difference } \\
\text { for the in-hospital } \\
\text { mortality between the } \\
\text { two groups. }\end{array}$ \\
\hline $\begin{array}{l}\text { Patorno et al. } \\
2014 \text { [16] }\end{array}$ & $\begin{array}{l}\text { Retrospective } \\
\text { observational study }\end{array}$ & $\begin{array}{l}\text { GA vs NA (spinal/ } \\
\text { epidural) vs. GA + NA }\end{array}$ & $\begin{array}{l}n=73.284 \\
G A=61.554(84.0 \%) \\
N A=6.939(9.47 \%) \\
G A+R A=4.791(6.53 \%)\end{array}$ & $\begin{array}{l}\text { In-hospital } \\
\text { mortality }\end{array}$ & $\begin{array}{l}\text { In-hospital mortality: } \\
\text { GA vs. NA: } 144 \text { vs. } 1362 \\
\text { (risk ratio } 0.93,95 \% \mathrm{Cl} \\
0.78 \text { to } 1.11 \text { ) }\end{array}$ & $\begin{array}{l}\text { Mortality risk did not } \\
\text { differ significantly } \\
\text { between GA and NA. }\end{array}$ \\
\hline
\end{tabular}




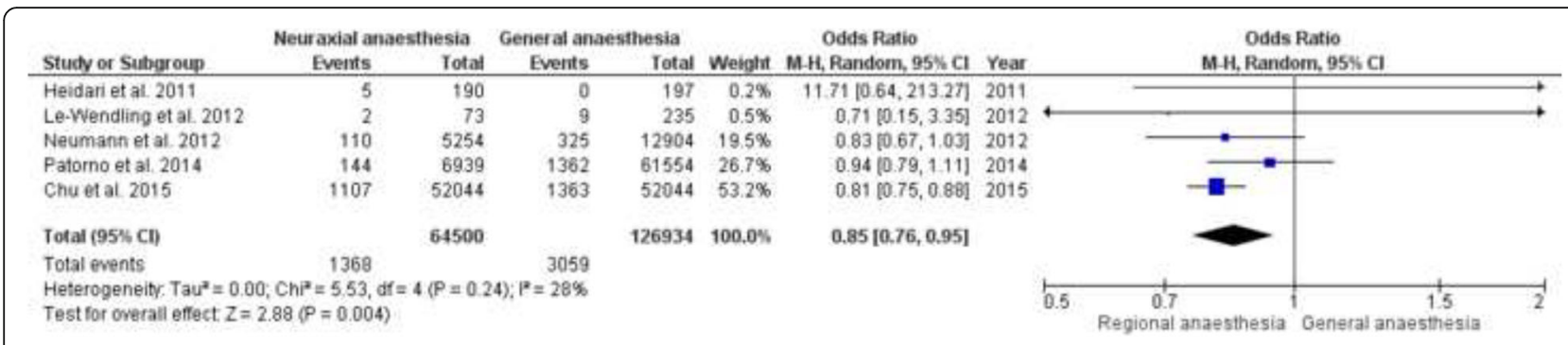

Fig. 3 Meta-analysis of the in-hospital mortality for the neuraxial anaesthesia groups versus the general anaesthesia group. The odds ratio was calculated with a random effect method

\section{Pulmonary complications}

Three studies examined the total rate of pulmonary complications after hip fracture surgery [10, 13, 27]. Helwani and colleagues and Neuman and colleagues reported that neuraxial anaesthesia is associated with a decreased risk of postoperative pulmonary complications [OR $0.51 ; 95 \%$ CI $(0.33$ to 0.81$) ; p<0.01$ ] [OR 0.752 , $95 \%$ CI $(0.637$ to 0.887$) ; p<0.0001][10,27]$. Kim and colleagues determined that the methods of anaesthesia did not influence the rate of pulmonary complications [13].

Nine studies analysed the incidence of pneumonia after general and neuraxial anaesthesia in patients with a hip fracture, see Table $8[8,9,18,19,22,24$, $27,31,33]$. The study of Shih and colleagues and Tung and colleagues revealed a significant higher incidence of pneumonia in the general anaesthesia group $[18,24]$. The other studies showed no difference between the two groups [8, 9, 19, 22, 27, 31, 33]. Eight of the nine studies could be included in a metaanalysis, see Fig. 6 [8, 9, 18, 19, 22, 24, 31, 33]. The meta-analysis revealed a similar incidence of pneumonia between the general and the neuraxial anaesthesia groups [OR $0.74,95 \%$ CI (0.46 to 1.17), $p=0.20]$. The heterogeneity is high $\left(\mathrm{I}^{2}=94 \%\right)$. The separate subgroup analysis of the retrospective observational studies revealed no significant difference between the examined groups [OR 0.72, 95\% CI (0.44 to 1.17$), p=0.18]$. The subgroup analysis of the randomised controlled indicate no difference between the two groups [OR 0.99, 95\% CI (0.21 to 4.76), $p=0.99$ ].

The incidence of postoperative pulmonary embolism was examined by four studies, see Table 8 [9, 19, 22, 31]. All studies revealed no difference between the general and the neuraxial groups. The study of Fields and colleagues, Parker and colleagues and Seitz and colleagues could be included in a meta-analysis, see Fig. $7[9,19,31]$. The meta-analysis showed no significant difference in the incidence of pulmonary embolism between the two groups [OR 0.86, 95\% CI (0.64 to 1.17$), p=0.35]$.
The incidence of respiratory failure was tested by three studies, see Table $8[18,25,27]$. The studies of Chu and colleagues and Neuman and colleagues indicated a significant higher incidence of respiratory failure in the general anaesthesia group [25, 27]. The study of Shih and colleagues revealed no difference between the two groups. All three studies were included in a metaanalysis $[18,25,27]$. The meta-analysis showed a significant lower incidence of respiratory failure in the neuraxial anaesthesia group [OR 0.50, 95\% CI (0.28 to 0.87), $p=0.02]$, see Fig. 8 .

\section{Discussion}

In our systematic review and meta-analysis we included 23 studies with 413.999 patients. 249.408 patients received general anaesthesia and 150.964 neuraxial anaesthesia (epidural/spinal). We could not detect any difference in the 30-day mortality in patients undergoing hip fracture surgery. However, the length of hospital stay and the in-hospital mortality were significantly shorter in the neuraxial anaesthesia group. Of the secondary outcomes the incidence of myocardial infarction and respiratory failure was significant lower in the neuraxial anaesthesia group. There was no difference in the incidence of pneumonia between the two groups. Of note, out of the 23 studies which met our inclusion criteria, 20 were mainly large retrospective observational studies and three were prospective randomised [8-30]. In 2010 a systematic review carried out by Luger and colleagues examined the type of anaesthesia in hip fracture surgery. They included literature from the years 1967 to 2010 in their systematic review. They were able to include 34 randomised studies, 14 observational studies and 8 systematic reviews and meta-analyses in their study. The authors speculated that spinal anaesthesia may be associated with significantly reduced early mortality, fewer incidents of deep vein thrombosis, less acute postoperative confusion, a tendency to fewer myocardial infarction, fewer cases of pneumonia, fatal pulmonary embolism and postoperative hypoxia [34]. However, the review was limited, as only 


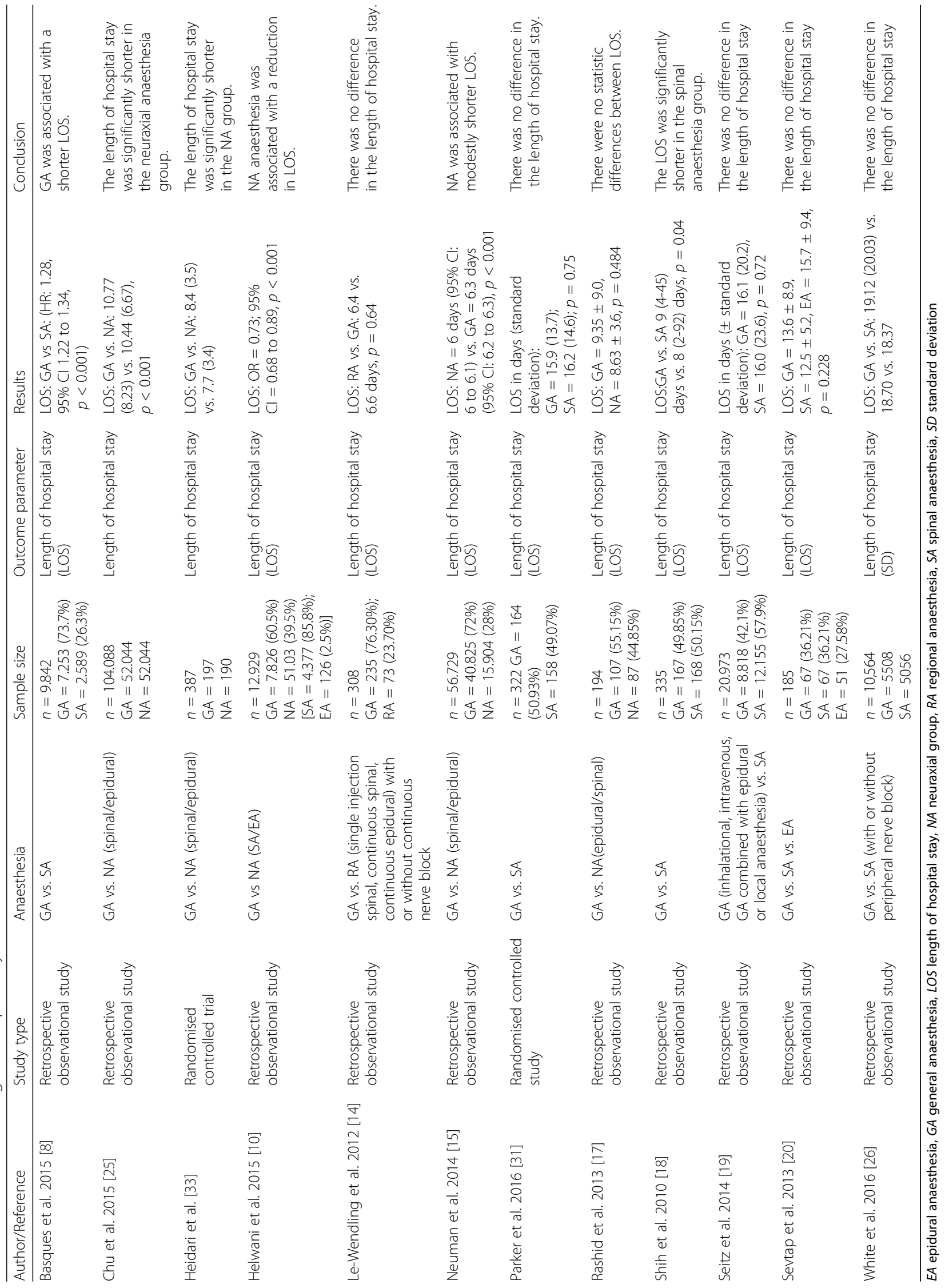




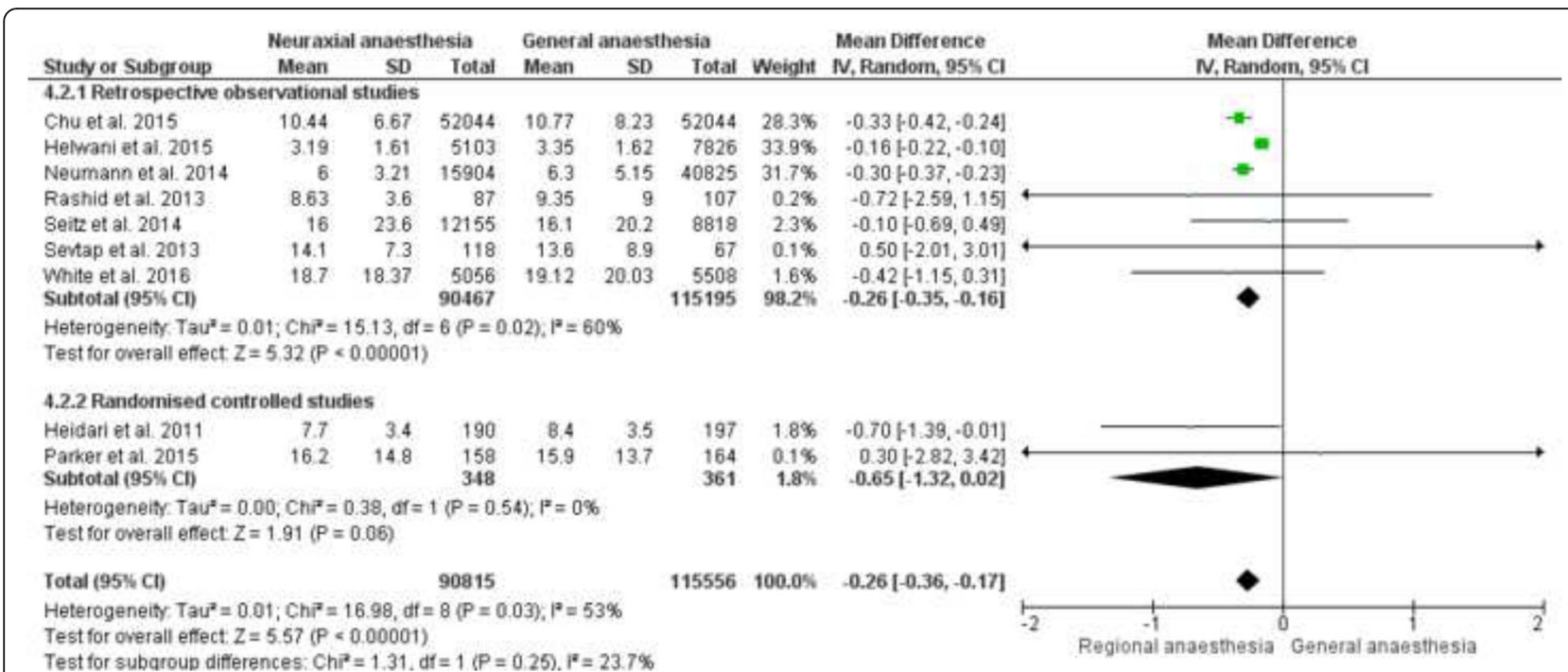

Fig. 4 Meta-analysis of the length of hospital stay for the neuraxial anaesthesia group versus the general anaesthesia group calculated with a random effect method. 4.2.1: Mean difference of the retrospective observational studies represented as a subgroup. 4.2.2: Mean difference of the randomised controlled studies represented as a subgroup

Table 7 Results of myocardial infarction

\begin{tabular}{|c|c|c|c|c|c|c|}
\hline $\begin{array}{l}\text { Author/ } \\
\text { Reference }\end{array}$ & Study type & Anaesthesia & Sample size & $\begin{array}{l}\text { Outcome } \\
\text { parameter }\end{array}$ & Results & Conclusion \\
\hline $\begin{array}{l}\text { Basques et al. } \\
2015 \text { [8] }\end{array}$ & $\begin{array}{l}\text { Retrospective } \\
\text { observational study }\end{array}$ & GA vs. SA & $\begin{array}{l}n=9.842 \\
\mathrm{GA}=7.253(73.7 \%) \\
\mathrm{SA}=2.589(26.3 \%)\end{array}$ & $\begin{array}{l}\text { Myocardial } \\
\text { infarction }\end{array}$ & $\begin{array}{l}\text { SA vs. GA: } 1.9 \% \text { vs. } 1.9 \% \\
\text { OR } 1.00,95 \% \mathrm{Cl} 0.71 \text { to } \\
1.39, p=0.510\end{array}$ & $\begin{array}{l}\text { The incidence of myocardial } \\
\text { infarction was similar in the } \\
\text { two groups. }\end{array}$ \\
\hline $\begin{array}{l}\text { Biboulet et al. } \\
2012 \text { [32] }\end{array}$ & $\begin{array}{l}\text { Randomised } \\
\text { controlled study }\end{array}$ & $\begin{array}{l}\text { GA vs. SA } \\
\text { (propofol, } \\
\text { sevoflurane) }\end{array}$ & $\begin{array}{l}n=45 \\
G A=30 \\
S A=15\end{array}$ & $\begin{array}{l}\text { Myocardial } \\
\text { infarction }\end{array}$ & $\begin{array}{l}\text { SA vs. GA: } 0 \text { vs. } 1 \\
p=1.0\end{array}$ & $\begin{array}{l}\text { The incidence of myocardial } \\
\text { infarction was similar } \\
\text { between the two groups. }\end{array}$ \\
\hline $\begin{array}{l}\text { Chu et al. } \\
2015 \text { [25] }\end{array}$ & $\begin{array}{l}\text { Retrospective } \\
\text { observational study }\end{array}$ & $\begin{array}{l}\text { GA vs. NA (spinal/ } \\
\text { epidural) }\end{array}$ & $\begin{array}{l}n=104.088 \\
\mathrm{GA}=52.044 \\
\mathrm{NA}=52.044\end{array}$ & $\begin{array}{l}\text { Myocardial } \\
\text { infarction }\end{array}$ & $\begin{array}{l}\text { NA vs. GA: } 169(0.32 \%) \\
\text { vs. } 188(0.36 \%), p=0.31\end{array}$ & $\begin{array}{l}\text { The incidence of myocardial } \\
\text { infarction was similar } \\
\text { between the two groups. }\end{array}$ \\
\hline $\begin{array}{l}\text { Fields et al. } \\
2010 \text { [9] }\end{array}$ & $\begin{array}{l}\text { Retrospective } \\
\text { observational study }\end{array}$ & GA vs. SA & $\begin{array}{l}n=6.133 \\
\mathrm{GA}=4.318(72.6 \%) \\
\mathrm{SA}=1.815(27.4 \%)\end{array}$ & $\begin{array}{l}\text { Myocardial } \\
\text { infarction }\end{array}$ & $\begin{array}{l}\text { SA vs. NA: } 1.71 \% \text { vs. } \\
1.75 \%, p=0.92\end{array}$ & $\begin{array}{l}\text { The incidence of myocardial } \\
\text { infarction was similar } \\
\text { between the two groups. }\end{array}$ \\
\hline $\begin{array}{l}\text { Heidari et al. } \\
2011 \text { [33] }\end{array}$ & $\begin{array}{l}\text { Randomised } \\
\text { controlled study }\end{array}$ & GA vs. NA (EA/SA) & $\begin{array}{l}n=270 \\
\mathrm{GA}=197 \\
\mathrm{NA}=190\end{array}$ & $\begin{array}{l}\text { Myocardial } \\
\text { infarction }\end{array}$ & $\begin{array}{l}\text { NA vs. GA: } 1(0.6 \%) \\
\text { vs. } 1(0.5 \%)\end{array}$ & $\begin{array}{l}\text { The incidence of myocardial } \\
\text { infarction was similar } \\
\text { between the two groups. }\end{array}$ \\
\hline $\begin{array}{l}\text { Neuman et al. } \\
2012 \text { [27] }\end{array}$ & $\begin{array}{l}\text { Retrospective } \\
\text { observational study }\end{array}$ & GA vs. NA & $\begin{array}{l}n=18.158 \\
\mathrm{GA}=12.904 \\
\mathrm{NA}=5.254\end{array}$ & $\begin{array}{l}\text { Myocardial } \\
\text { infarction }\end{array}$ & $\begin{array}{l}\text { NA vs. GA: } 97(1.9 \%) \text { vs. } \\
266(2.1 \%), p=0.348\end{array}$ & $\begin{array}{l}\text { The incidence of myocardial } \\
\text { infarction was similar } \\
\text { between the two groups. }\end{array}$ \\
\hline $\begin{array}{l}\text { Parker et al. } \\
2015 \text { [31] }\end{array}$ & $\begin{array}{l}\text { Randomised } \\
\text { controlled study }\end{array}$ & GA vs. SA & $\begin{array}{l}n=322 \\
G A=164(50.93 \%) \\
S A=158(49.07 \%)\end{array}$ & $\begin{array}{l}\text { Myocardial } \\
\text { infarction }\end{array}$ & $\begin{array}{l}\text { SA vs. GA: } 1(0.6 \%) \\
\text { vs. } 1(0.6 \%), p=1.0\end{array}$ & $\begin{array}{l}\text { The incidence of myocardial } \\
\text { infarction was similar } \\
\text { between the two groups. }\end{array}$ \\
\hline $\begin{array}{l}\text { Seitz et al. } \\
2014 \text { [19] }\end{array}$ & $\begin{array}{l}\text { Retrospective } \\
\text { observational study }\end{array}$ & $\begin{array}{l}\text { GA (inhalational, } \\
\text { intravenous, GA } \\
\text { combined with } \\
\text { epidural or local } \\
\text { anaesthesia) vs. SA }\end{array}$ & $\begin{array}{l}n=20.973 \\
\mathrm{GA}=8.818(42.1 \%) \\
\mathrm{SA}=12.155(57.9 \%)\end{array}$ & $\begin{array}{l}\text { Myocardial } \\
\text { infarction }\end{array}$ & $\begin{array}{l}\text { SA vs. GA: } 454(7.4 \%) \\
\text { vs. } 501(8.2 \%), p=0.07\end{array}$ & $\begin{array}{l}\text { The incidence of myocardial } \\
\text { infarction was similar } \\
\text { between the two groups. }\end{array}$ \\
\hline $\begin{array}{l}\text { Tung et al. } \\
2016 \text { [24] }\end{array}$ & $\begin{array}{l}\text { Retrospective } \\
\text { observational study }\end{array}$ & $\begin{array}{l}\text { GA vs. RA } \\
\text { (epidural/spinal) }\end{array}$ & $\begin{array}{l}n=17.189 \\
\mathrm{GA}=6.063(35.1 \%) \\
\mathrm{NA}=11.153(64.9 \%)\end{array}$ & $\begin{array}{l}\text { Myocardial } \\
\text { infarction }\end{array}$ & $\begin{array}{l}\text { NA vs. GA: } 10(0.1 \%) \\
\text { vs. } 10(0.1 \%), p=0.162\end{array}$ & $\begin{array}{l}\text { The incidence of myocardial } \\
\text { infarction was similar } \\
\text { between the two groups. }\end{array}$ \\
\hline $\begin{array}{l}\text { Whiting et al. } \\
2015 \text { [22] }\end{array}$ & $\begin{array}{l}\text { Retrospective } \\
\text { observational study }\end{array}$ & GA vs. SA & $\begin{array}{l}n=7.764 \\
\mathrm{GA}=5.840 \\
\mathrm{SA}=1.813\end{array}$ & $\begin{array}{l}\text { Myocardial } \\
\text { infarction }\end{array}$ & $\begin{array}{l}\text { SA vs. GA: Odds ratio } \\
0.84 ; 95 \% \text { Cl 0.50-1.43, } \\
p=0.532\end{array}$ & $\begin{array}{l}\text { The incidence of myocardial } \\
\text { infarction was similar } \\
\text { between the two groups. }\end{array}$ \\
\hline
\end{tabular}




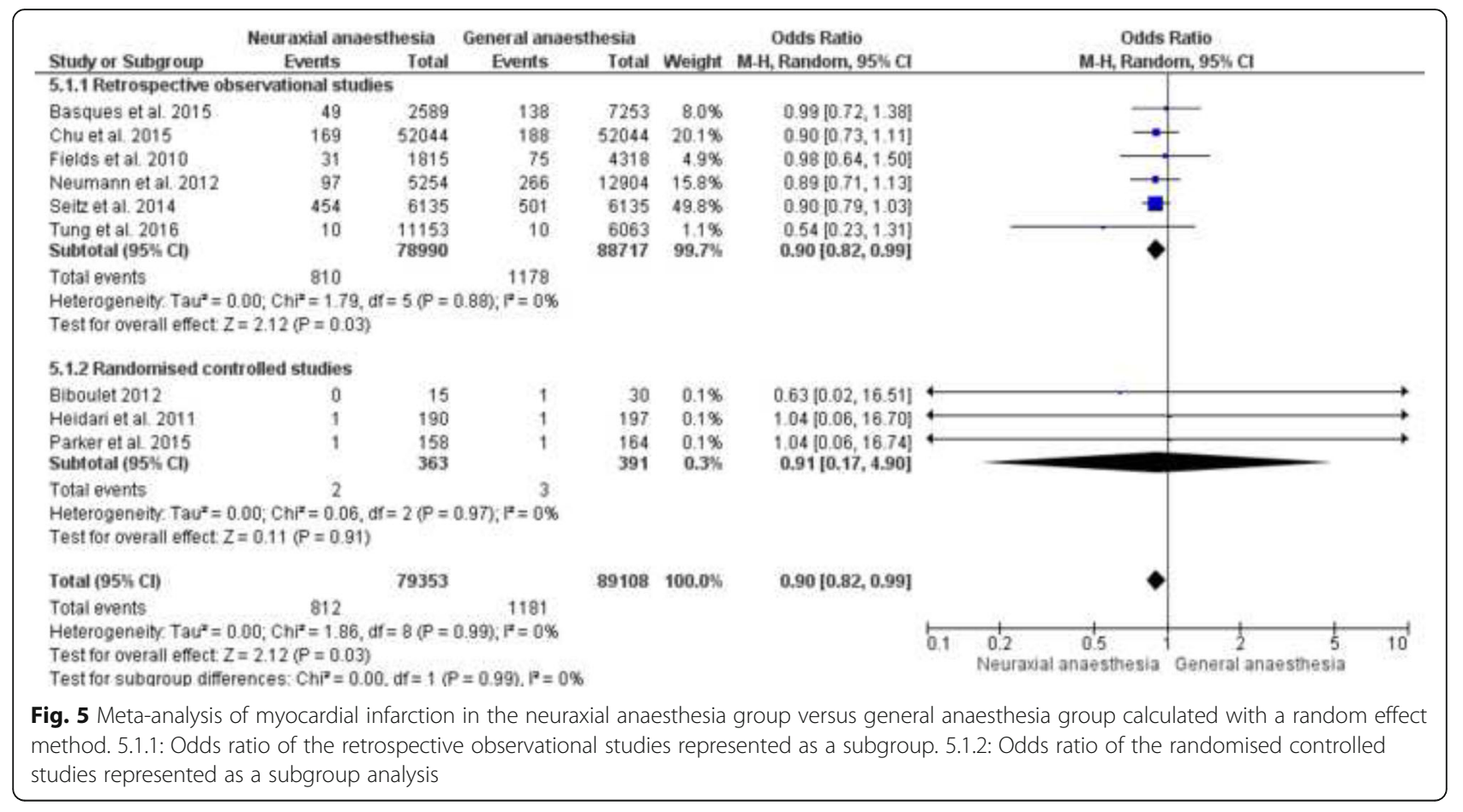

18.715 patients were included. With regard to the limited evidence the authors concluded that, neither general, nor regional anaesthesia seem to improve perioperative outcome [34]. To the best of our knowledge, the most recent effort to bundle information in a systematic review addressing the type of anaesthesia in hip fracture surgery has been performed in 2016 by Guay and colleagues in a Cochrane Review. They included only randomised studies from 2003 to 2014. In total 31 studies were included with 3231 patients. Furthermore, only 2152 patients were available to examine the 30-day mortality. They did not find a difference between the two techniques. The authors determined that the number of patients included in the study was insufficient to reveal a difference between general and regional anaesthesia in hip fracture patients [7]. For these reasons we decided to include both prospective randomised and retrospective observational studies to assess as many patients as possible for the systematic review and the meta-analyses. In our systematic review and meta-analysis fourteen studies assessed the 30-day mortality. However, the high number of patients is limited through the high risk of selection bias.

As mentioned above two studies assessed the overall-mortality. Karaman and colleagues revealed that there is a higher mortality rate after receiving general than neuraxial anaesthesia [12]. Shih and colleagues concluded that there is no significant difference between the general and the neuraxial anaesthesia group [18]. Though, there are some limitations. For Karaman and colleagues the overallmortality was defined as the mortality rate during the length of stay and the follow-up time [12]. Follow-up time was defined as the time period of the study duration. The follow-up time fluctuated between zero and 60 months [12]. For Shih and colleagues overallmortality means the incidence of death since discharge. Obviously it is not possible to compare these two overall-mortalities. The neuraxial anaesthesia group of Karaman and colleagues included spinal and epidural anaesthesia [12]. The neuraxial anaesthesia group of Shih and colleagues included only spinal anaesthesia. [19].

Five other studies examined the in-hospital mortality $[14,16,25,27,33]$. The study of Chu et al. revealed a significant higher incidence of in-hospital mortality in the general anaesthesia group [25]. The meta-analysis of the in-hospital mortality showed therefore a significant higher incidence of in-hospital mortality in the general anaesthesia group. [14, 16, $25,27,33]$ The study of $\mathrm{Chu}$ et al. included 104.088 patients in their study and is weighted in the analysis with 53.2\% [25]. The other studies are considerable smaller $[14,16,27,33]$. The conclusion of the metaanalysis is therefore limited. However the 30-day mortality rate revealed no difference between the groups. It seems like, if the patient survives the hospital stay, 


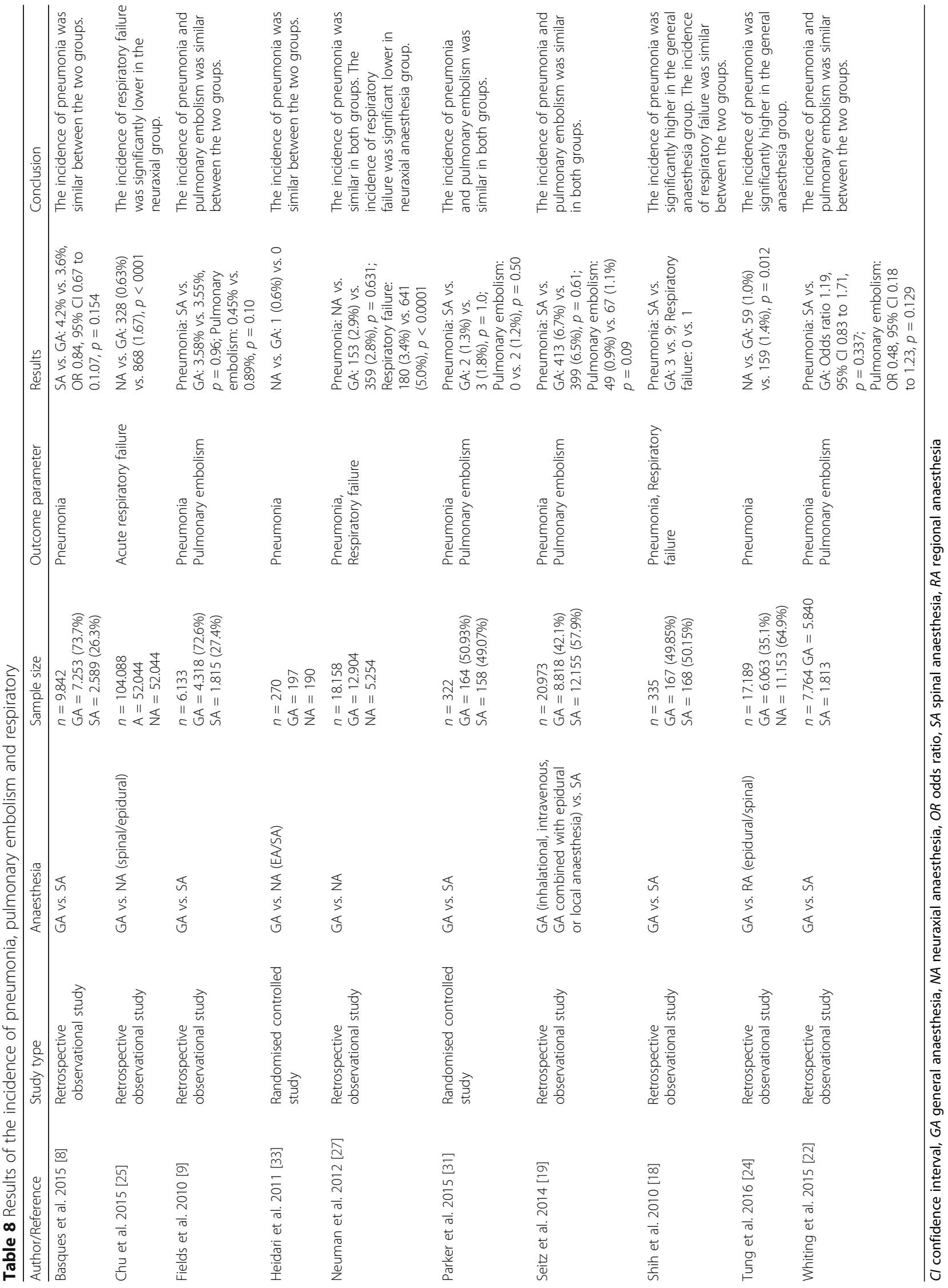




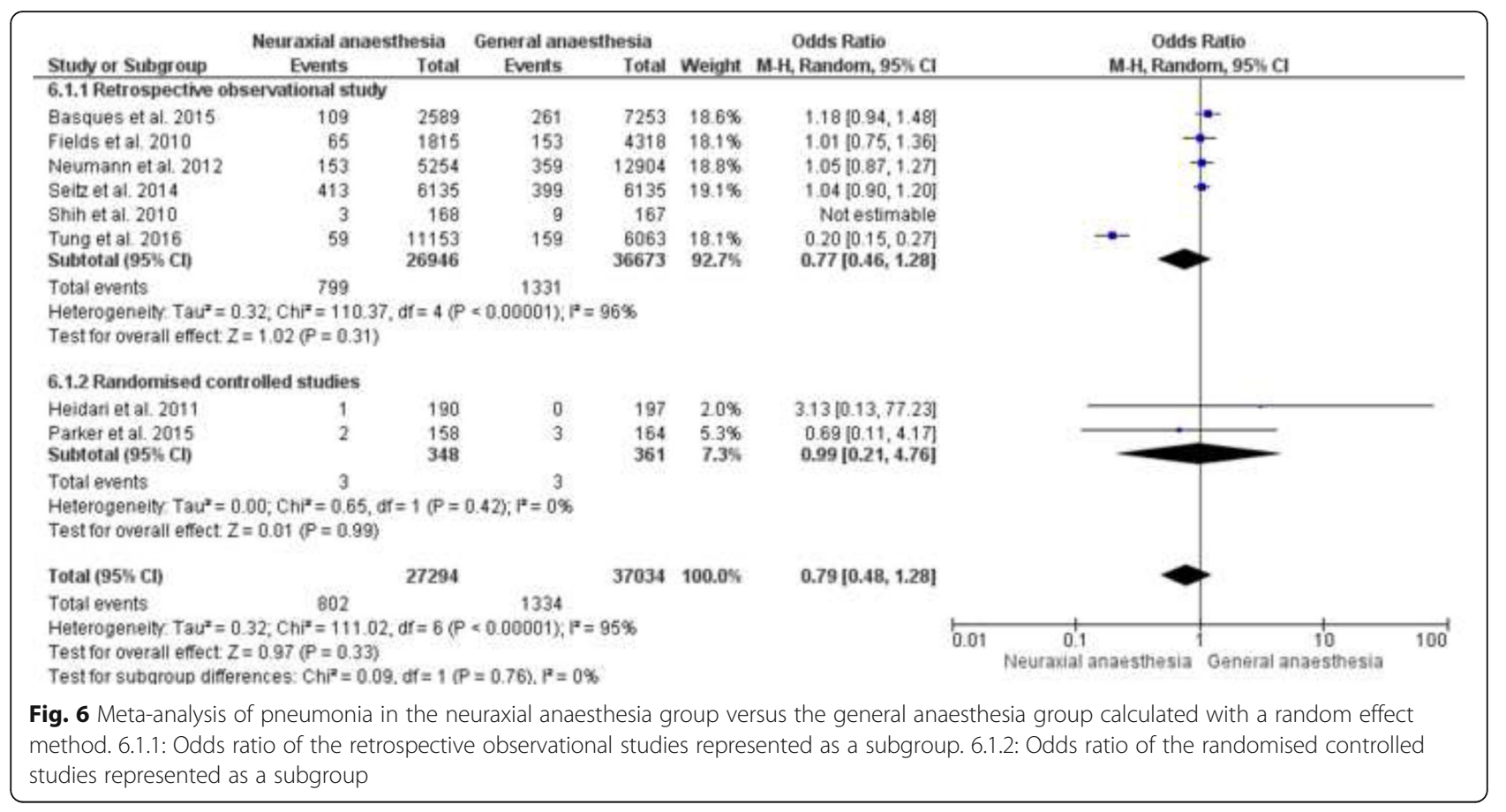

the risk to die in the next weeks is equal whatever anaesthesia technique was applied. Due to aforementioned limitations of the meta-analyses, there is an urge of randomised controlled studies examining the effect of anaesthesia technique regarding the inhospital and 30-day mortality rates, taking into account possible influencing variables like the age of the patients, pre-existing conditions and type of surgery.

We found a significant shorter length of stay in the neuraxial anaesthesia group compared to the general anaesthesia group. We could include nine studies out of twelve $[10,15,17,19,20,25,26,31,33]$. The other three studies did not mentioned the standard deviation $[8,14,19]$. Due to non-response it was impossible to receive the missing parameters from the authors. Only four studies in the meta-analysis revealed a significant shorter length of stay in the neuraxial anaesthesia group. Three of them are the studies getting the most weight in the analysis $[10$,
15, 25]. Therefore our results have to be interpreted with caution. The meta-analysis revealed that the length of hospital stay is one quarter of a day shorter in the neuraxial anaesthesia group, which most likely has no clinical relevance. Another problem is the different definition of the meaning of length of hospital stay. Most of the authors documented the overall length of stay. In contrast the study of Heidari and colleagues represent the length of stay before and after the surgery [33]. This is an important point, because a delay of surgery extends the length of stay. Helwani and colleagues and Neuman and colleagues showed that neuraxial anaesthesia is associated with a modestly shorter length of stay $[10,15]$. In the study of Neuman and colleagues the authors considered the fracture type and the performed surgery procedure [15]. Minimally invasive approaches may decrease the length of stay. Kazemian and colleagues published in 2013 a randomised controlled study examining the treatment of

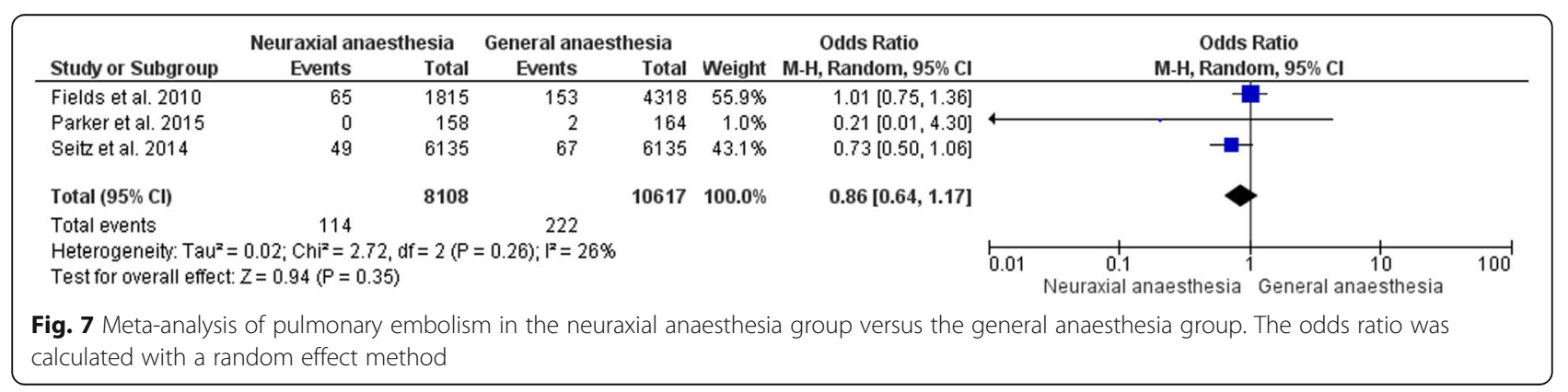




\begin{tabular}{|c|c|c|c|c|c|c|c|c|c|}
\hline \multirow{2}{*}{ Study or Subgroup } & \multicolumn{2}{|c|}{ Neuraxial anaesthesia } & \multicolumn{2}{|c|}{ General anaesthesia } & Weight & \multirow{2}{*}{$\begin{array}{l}\text { Odds Ratio } \\
\text { M-H, Random, } 95 \% \mathrm{Cl}\end{array}$} & \multirow{2}{*}{\multicolumn{3}{|c|}{$\begin{array}{c}\text { Odds Ratio } \\
\text { M- } \mathrm{H}, \text { Random, } 95 \% \mathrm{Cl} \\
\end{array}$}} \\
\hline & $\begin{array}{r}\text { Events } \\
338\end{array}$ & $\frac{\text { lotal }}{53044}$ & $\begin{array}{r}\text { Events } \\
868\end{array}$ & $\frac{\text { lotal }}{53044}$ & $\frac{1}{490 \%}$ & & & & \\
\hline Neumann et al. 2012 & 180 & 5254 & 641 & 12904 & $48.1 \%$ & $0.68[0.57,0.80]$ & \multirow{2}{*}{ - } & & \\
\hline Shih et al. 2010 & 0 & 168 & 1 & 167 & $2.9 \%$ & $0.33[0.01,8.14]$ & & & \\
\hline Total $(95 \% \mathrm{Cl})$ & \multicolumn{2}{|r|}{57466} & \multicolumn{2}{|r|}{65115} & $100.0 \%$ & \multirow[t]{2}{*}{$0.50[0.28,0.87]$} & & & \\
\hline \multirow{2}{*}{\multicolumn{5}{|c|}{$\begin{array}{l}\text { Heterogeneity: } \operatorname{Tau}^{2}=0.17 ; \mathrm{Chi}^{2}=30.59, \mathrm{df}=2(\mathrm{P}<0.00001) ; \mathrm{I}^{2}=93 \% \\
\text { Test for overall effect: } Z=2.43(\mathrm{P}=0.02)\end{array}$}} & & & & & \\
\hline & & & & & & & $\begin{array}{|cc|}0.01 & 0.1 \\
& \text { Neuraxial anaesthesia }\end{array}$ & $\begin{array}{c}10 \\
10 \\
\text { Neuraxial anaesthesia }\end{array}$ & 100 \\
\hline
\end{tabular}

intertrochanteric fractures in elderly patients by a dynamic hip screw and external fixation. The treatment of the hip fracture with the minimal-invasive external fixation showed minimal blood loss, pain reduction, shorter length of hospital stay and favourable functional outcomes compared to the dynamic hip screw [35]. Basques and colleagues revealed that general anaesthesia is associated with a shorter length of stay. However, patients receiving a general anaesthesia were younger, had higher Body Mass Index (BMI) and less comorbidities [8]. The authors used a propensity score to reduce the selection bias and the differences between the two groups, but the length of hospital length of stay was shorter in the general anaesthesia group. The question remains unanswered, if the length of stay in this group was shorter because the patients received general anaesthesia or due to the fact that patients were younger and did not have as many chronic diseases as the older patients who received a spinal anaesthesia. After all the risk of selection bias is high. Another important limitation is the different health care systems of the four included studies for the meta-analysis. The study of Seitz and colleagues and Helwani and colleagues were performed in the United States of America, the study of Sevtap and colleagues in Turkey and the study of Rashid and colleagues in Pakistan $[10,17-20]$. Caution is advised when comparing the length of hospital stay of patients with hip fracture in different countries with differing health care systems and discharge points.

In addition we investigated the incidence of myocardial infarction, pneumonia and pulmonary embolism between general and neuraxial anaesthesia after hip fracture surgery. The meta-analysis of the myocardial infarction revealed a significant higher incidence of myocardial infarction in the general anaesthesia group. However, the meta-analysis has got several limitations. All nine studies showed no difference between the two groups. A considerable bias was introduced by the retrospective observational studies. The result of the meta-analysis has to be interpreted with caution.
The meta-analysis of the incidence of postoperative pneumonia indicated no difference between the general and neuraxial anaesthesia groups. Only the study of Shih and colleagues revealed a significant higher incidence of pneumonia in the general anaesthesia group. However the study had only a small sample size of 335 patients [18]. Kamel and colleagues examined 2003 in a study the time to ambulation (walking) after hip fracture surgery. In this study the type of anaesthesia had no influence of the time to ambulation after a hip fracture surgery. However, a prolonged time to ambulation was associated with a longer length of stay and a higher incidence of pneumonia [36].

The meta-analysis of the incidence of the pulmonary embolism showed no significant difference between the general and the neuraxial anaesthesia group. The validity of the meta-analysis regarding pulmonary embolism is limited by the inclusion of only four studies.

This systematic review and meta-analysis has several important limitations. 20 from 23 included studies were retrospective observational studies and only three were randomised [8-27, 31-33]. Retrospective studies have a high risk for selection bias, confounding factors and unobserved differences between the neuraxial and the general anaesthesia group. Most of the authors used a propensity score to reduce the risk of bias, but randomised studies would be preferable $[8-16,18-26]$. On the other hand the retrospective studies in this review included overall 413.999 patients. The data for the studies were obtained from databases like ACS-NSQIP (American College of Surgeons National Quality Improvement program). The database considered 135 variables, including preoperative risk factors, 30-day mortality, overall-mortality, surgical site infection etc. [37]. Many patients had to be excluded because of incomplete documents. Most of the studies did not describe the dosage and the type of the anaesthetic used. Only the paper of Shih and colleagues and Sevtap and colleagues described the dosage and the type of anaesthetic in detail $[18,20]$. In 20 of the 23 
studies no information is available whether patients with neuraxial anaesthesia received additional sedation. Shih and colleagues, White and colleagues and Heidari and colleagues are the only authors who mentioned if there was a sedation used [18, 26, 33]. The sample size of the included studies varied widely. However, RevMan weights the studies according to the precision of the effect size. Therefore, we decided to include also small studies. Another limitation is the restricted set of outcomes. We were not able to examine functional outcome or disability-free survival. In addition, it would be advisable for future systematic reviews and metaanalyses to take studies assessing the effect of types of surgery [38], applied anaesthetics and their dosage [39] into consideration.

\section{Conclusion}

In this meta-analysis we could not observe any difference in the 30-day mortality rate between neuraxial and general anaesthesia. Length of hospital stay and the inhospital mortality was shorter in the neuraxial anaesthesia group. There is an urgent need to carry out large randomised studies, which will reflect "real world" approaches to general and neuraxial anaesthesia, like e.g. the REGAIN trial (www.regaintrial.org.).

\section{Abbreviations \\ ACS-NSQIP: American College of Surgeons National Quality Improvement program; AS: Ana Stevanovic; BMI: Body mass index; Cl: Confidence Interval; Cvc: Cardiovascular complications; Dssi: Deep surgical site infection; EA: Epidural anaesthesia; GA: General anaesthesia; HR: Hazard ratio; Hz: Hospitalization costs; $I^{2}$ : Heterogeneity; ICTRP: International clinical trials registry platform; IQR: Interquartile range; JWW: Julia Van Waesberghe; LOS: Length of hospital stay; MC: Mark Coburn; MD: Mean difference; NA: Neuraxial anaesthesia; OR: Odds ratio; Pc: Pulmonary complications; RA: Regional anaesthesia; RR: Rolf Rossaint; SA: Spinal anaesthesia; SD: Standard deviation}

\section{Acknowledgements}

We wish to thank Monroe Coburn for his editorial suggestions.

\section{Funding}

This research received no specific grant from any funding agency in the public, commercial or not-for-profit sectors.

\section{Availability of data and material}

All data generated or analysed during this study are included in this published article.

\section{Author's contribution}

The literature search was performed by JWW and all hits were screened and reviewed for eligibility by $A S$ and $M C$ independently. The manuscript was drafted by JWW and critically reviewed and edited by AS, RR and MC. All authors read and approved the final manuscript

Ethics approval and consent to participate Not applicable.

\section{Consent for publication}

Not applicable.

\section{Competing interests}

The authors declare that they have no competing interests.

\section{Publisher's Note}

Springer Nature remains neutral with regard to jurisdictional claims in published maps and institutional affiliations.

Received: 21 December 2016 Accepted: 21 June 2017

Published online: 28 June 2017

\section{References}

1. Dhanwal DK, Dennison EM, Harvey NC, Cooper C. Epidemiology of hip fracture: worldwide geographic variation. Indian J Orthop. 2011;45:15-22.

2. Haentjens P, Magaziner J, Colon-Emeric CS, Vanderschueren D, Milisen K, Velkeniers $B$, et al. Meta-analysis: excess mortality after hip fracture among old women and men. Ann Intern Med. 2010;152:380-90.

3. Royal College of Physicians. National hip Fracture Database (NHFD) annual report 2015. London: RCP; 2015.

4. Johnell $O$, Kanis JA. An estimate of the worldwide prevalence, mortality and disability associated with hip fracture. Osteoporos Int. 2006:17:1726-33.

5. Association of Anaesthetists of Great Britain and Ireland, Griffiths R, Alper J, Beckingsale A, Goldhill D, Heyburn G, et al. Management of proximal femoral fractures 2011: Association of Anaesthetists of Great Britain and Ireland. Anaesthesia. 2012:6785-98.

6. Medin E, Goude F, Melberg HO, Tediosi F, Belicza E, Peltola M, et al. European regional differences in all-cause mortality and length of stay for hip fracture patients [abstract]. Health Econ. 2015;24:53-64.

7. Guay J, Parker MJ, Gajendragadkar PR, Kopp S. Anaesthesia for hip fracture surgery in adults. Cochrane Database of Systematic Reviews 2016, Issue 2. Art. No.: CD000521. DOl: 10.1002/14651858.CD000521

8. Basques BA, Bohl DD, Golinvaux NS, Samuel AM, Grauer JG. General versus spinal anaesthesia for patients aged 70 years and older with a fracture of the hip. Bone joint J. 2015;97-B:689-95.

9. Fields AC, Dietrich JD, Buterbaugh K, Moucha CS. Short-term complications in hip fracture surgery using spinal versus general anesthesia. Injury. 2015: 46719-23.

10. Helwani MH, Avidan MS, Ben Abdallah A, Kaiser DJ, Clohisy JC, Hall BL, et al. Effects of regional versus general anesthesia on outcomes after total hip arthroplasty. J Bone Joint Surg Am. 2015;97:186-93.

11. Karademir G, Bilgin Y, Ersen A, Polat G, Buget Ml, Demirel M, et al. Hip fractures in patients older than 75 years old: retrospective analysis for prognostic factors. Int J Surg. 2015;24:101-4.

12. Karaman Ö, Özkazanli G, Orak MM, Mutlu H, Caliskan G, Karakus Ö, et al. Factors affecting postoperative mortality in patients older than 65 years undergoing surgery for hip fracture. Ulus Travma Acil Cerrahi Derq. 2015;21: 44-50.

13. Kim SD, Park SJ, Lee DH, Jee DL. Risk factors of morbidity and mortality following hip fracture surgery. Korean J Anesthesiol. 2013;64: 505-10.

14. Le-Wendling L, Bihorac A, Baslanti TO, Lucas S, Sadasivan K, Wendling A, et al. Regional anesthesia as compared with general anesthesia for surgery in geriatric patients with hip fracture: does it decrease morbidity, mortality, and health care costs? Results of a single-centered study. Pain Med. 2012;13: 948-56

15. Neuman MD, Rosenbaum PR, Ludwiq JM, Zubizarreta JR, Silber JH. Anesthesia technique, mortality, and length of stay after hip fracture surgery. JAMA. 2014;25(311):2508-17.

16. Patorno E, Neumann MD, Schneeweiss S, Mogun H, Bateman BT. Comparative safety of anesthetic type for hip fracture surgery in adults: retrospective cohort study. BMJ. 2014;348:g4022.

17. Rashid RH, Shah AA, Shakoor A, Noordin S. Hip fracture surgery: does type of anesthesia matter? Biomed Res Int. Volume 2013 doi:10.1155/ 2013/252356

18. Shih Y-J, Hsieh C-H, Kang T-W, Peng S-Y, Fan K-T, Wang L-M, et al. General versus spinal anesthesia: which is a risk factor for octogenarian hip fracture repair patients? Int J Gerontol. 2010;4:37-42.

19. Seitz DP, Gill SS, Bell CM, Austin PC, Anderson GM, et al. A postoperative medical complications associated with anesthesia on older adults with dementia. J Am Geriatr Soc. 2014;62:2102-9. 
20. Sevtap HS, Nurettin H, Alkin C, Necdet S. Comparison of different anesthetic techniques on postoperative outcomes in elderly patients with hip fracture. Turkiye Klinikleri J Med Sci. 2012;32:623-9.

21. White SM, Moppett IK, Griffiths R. Outcome by mode of anaesthesia for hip fracture surgery. An observational audit of 65535 patients in a national dataset. Anaesthesia. 2014;69:224-30.

22. Whiting PS, Molina CS, Greenberg SE, Thakore RV, Obremskey WT, Sethi MK. Regional Anaesthesia for hip fracture surgery is associated with significantly more peri-operative complications compared with general anaesthesia. Int Orthop. 2015;39:1321-7.

23. Brox WT, Chan PH, Cafri G, Inacio MC. Similar mortality with general or regional anesthesia in elderly hip fracture patients. Acta Orthop. 2016;87: 152-7.

24. Tung Y-C, Hsu Y-H, Chang G-M. The effect of anesthetic type on outcomes of hip fracture surgery. Medicine (Baltimore). 2016;95:e3296.

25. Chu CC, Weng SF, Chen KT, Chien CC, Shieh JP, Chen JY, et al. Propensity score-matched comparison of postoperative adverse outcomes between geriatric patients given a general or a neuraxial anesthetic for hip surgery: a population-based study. Anesthesiology. 2015;123:136-47.

26. White SM, Moppett IK, Griffiths R, Johansen A, Wakeman R, Boulton C, et al. Secondary analysis of outcomes after 11,085 hip fracture operations from the prospective UK Anaesthesia Sprint audit of practice (ASAP-2). Anaesthesia. 2016;71:506-14.

27. Neuman MD, Silber JH, Elkassabany NM. Comparative effectiveness of regional versus general anesthesia for hip fracture surgery in adults. Anesthesiology. 2012;117:72-92.

28. Liberati A, Altman DG, Tetzlaff J, Mulrow C, Gotsche P, loannidis JPA, et al. The PRISMA statement for reporting systematic reviews and meta-analyses of studies that evaluate healthcare interventions: explanation and elaboration. BMJ. 2009;339:b2700

29. Basques BA, Bohl DD, Golinvaux NS, Leslie MP, Baumgartner MR, Grauer $\mathrm{JN}$. Postoperative length of stay and 30-day readmission after geriatric hip fracture: an analysis of 8434 patients. J Orthop Trauma. 2015;29: 115-20.

30. Zhao P, Lian X, Dou X, Bi Q, Quan R, Tong P, et al. Intertrochanteric hip fracture surgery in Chinese: risk factors for predicting mortality. Int J Clin Exp Med. 2015:8:2789-93.

31. Parker MJ, Griffiths R. General versus regional anaesthesia for hip fractures. A pilot randomised controlled trial of 322 patients. Injury. 2015:48:1562-6.

32. Biboulet $P$, Jourdan A, Van Haevre V, Morau D, Bernard N, Brinquier S, et al. Hemodynamic profile of target-controlled spinal anesthesia compared with 2 target-controlled general anesthesia techniques in elderly patients with cardiac comorbidities. Reg Anesth Pain Med. 2012;37:433-40.

33. Heidari SA, Soltani H, Hashemi SJ, Talakoub R, Soleimani B. Comparative study of two anesthesia methods according to postoperative complications and one month mortality rate in the candidates of hip surgery. J Res Med Sci. 2011;16:323-30.

34. Luger TJ, Kammerlander C, Gosch M, Luger MF, Kammerlander-Knauer U, Roth $T$ et al. Neuroaxial versus general anaesthesia in geriatric patients for hip fracture surgery: does it matter [abstract]? Osteoporos Int. 2010 21S555-72.

35. Kazemian GH, Manafi AR, Najafi F, Najafi MA. Treatment of intertrochanteric fractures in elderly high risk patients: dynamic hip screw vs. external fixation. Injury. 2014;45:568-72.

36. Kamel HK, Iqbal MA, Mogallapu R, Maas D, Hoffmann RG. Time to ambulation after hip fracture surgery: relation to hospitalization outcomes. J Gerontol A Biol Sci Med Sci. 2003;58:1042-5.

37. American College of Surgeons National Surgical Quality Improvement Program $^{\oplus}$ (ACS NSQIP ${ }^{\oplus}$ ) available from https://www.facs.org/qualityprograms/acs-nsqip

38. Fixation using Alternative Implants for the treatment of Hip fractures (FAITH) Investigators. Fracture fixation in the operative management of hip fractures (FAITH): an international, multicentre, randomised controlled trial. Lancet. 2017;389:1519-27.

39. Errando $\mathrm{CL}$, Soriano-Bru JL, Peiro CM, Ubeda J. Single shot spinal anaesthesia with hypobaric bupivacaine for hip fracture repair surgery in the elderly. Randomize, double blinded comparison of $3.75 \mathrm{mg}$ vs. $7.5 \mathrm{mg}$ Rev Esp Anestesiol Reanim. 2014;61:541-8.

\section{Submit your next manuscript to BioMed Central and we will help you at every step:}

- We accept pre-submission inquiries

- Our selector tool helps you to find the most relevant journal

- We provide round the clock customer support

- Convenient online submission

- Thorough peer review

- Inclusion in PubMed and all major indexing services

- Maximum visibility for your research

Submit your manuscript at www.biomedcentral.com/submit 